\title{
Actions of Brain-Derived Neurotrophic Factor in Slices from Rats with Spontaneous Seizures and Mossy Fiber Sprouting in the Dentate Gyrus
}

\author{
Helen E. Scharfman, ${ }^{1,2}$ Jeffrey H. Goodman, ${ }^{1}$ and Anne L. Sollas ${ }^{1}$ \\ ${ }^{1}$ Neurology Research Center, Helen Hayes Hospital, West Haverstraw, New York 10993-1195, and 2Departments of \\ Pharmacology and Neurology, Columbia University, College of Physicians and Surgeons, New York, New York 10032
}

This study examined the acute actions of brain-derived neurotrophic factor (BDNF) in the rat dentate gyrus after seizures, because previous studies have shown that BDNF has acute effects on dentate granule cell synaptic transmission, and other studies have demonstrated that BDNF expression increases in granule cells after seizures.

Pilocarpine-treated rats were studied because they not only have seizures and increased BDNF expression in granule cells, but they also have reorganization of granule cell "mossy fiber" axons. This reorganization, referred to as "sprouting," involves collaterals that grow into novel areas, i.e., the inner molecular layer, where granule cell and interneuron dendrites are located. Thus, this animal model allowed us to address the effects of BDNF in the dentate gyrus after seizures, as well as the actions of BDNF on mossy fiber transmission after reorganization.

In slices with sprouting, BDNF bath application enhanced responses recorded in the inner molecular layer to mossy fiber stimulation. Spontaneous bursts of granule cells occurred, and these were apparently generated at the site of the sprouted axon plexus. These effects were not accompanied by major changes in perforant path-evoked responses or paired-pulse inhibition, occurred only after prolonged (30-60 min) exposure to BDNF, and were blocked by K252a.

The results suggest a preferential action of BDNF at mossy fiber synapses, even after substantial changes in the dentate gyrus network. Moreover, the results suggest that activation of trkB receptors could contribute to the hyperexcitability observed in animals with sprouting. Because human granule cells also express increased BDNF mRNA after seizures, and sprouting can occur in temporal lobe epileptics, the results may have implications for understanding temporal lobe epilepsy.

Key words: neurotrophin; growth factor; hippocampus; epilepsy; glutamate; tyrosine kinase
BDNF is widely recognized as a neurotrophin with an important role in normal development that has both trophic and protective effects (Hofer and Barde, 1988; Alderson et al., 1990; Knüsel et al., 1991; Spina et al., 1992; Yan et al., 1992; Lindholm et al., 1993; Morse et al., 1993; Beck et al., 1994; Cheng and Mattson et al., 1994; Ghosh et al., 1994; Kokaia et al., 1994; Acheson et al., 1995; McAllister et al., 1995; Lowenstein and Arsenault, 1996). More recently it has become clear that BDNF also has acute, neuromodulatory effects on synaptic transmission. Lohof et al. (1993) first demonstrated that exposure of neuromuscular cultures to BDNF led to increased EPSCs, and this was followed by reports of related effects in other systems (Le $\beta$ man et al., 1994; Kang and Schuman, 1995; Levine et al., 1995, 1996; Figurov et al., 1996; Patterson et al., 1996; Carmignoto et al., 1997; Le $\beta$ man and Heumann, 1998; Messaoudi et al., 1998). Most studies indicate that the high-affinity receptor for BDNF, trkB, mediates BDNF's actions (Kang and Schuman, 1995; Levine et al., 1995, 1996; Figurov et al., 1996; Carmignoto et al., 1997; Le $\beta$ man and Heumann, 1998; Li et al., 1998).

\footnotetext{
Received Feb. 5, 1999; revised April 8, 1999; accepted April 14, 1999.

This study was supported by National Institute of Neurological Diseases and Stroke Grant NS 37562 (H.E.S.) and the Helen Hayes Hospital Foundation. We thank Regeneron Pharmaceuticals, Inc., for their generous gift of BDNF and antisera to BDNF, and Dr. Susan Croll, Dr. John Rudge, and Dr. Stanley Wiegand for their suggestions throughout this project and their assistance with immunocytochemistry. We thank Annmarie Curcio for secretarial assistance.

Correspondence should be addressed to Dr. Helen E. Scharfman, Neurology Research Center, Helen Hayes Hospital, West Haverstraw, NY 10993-1195. Copyright (C) 1999 Society for Neuroscience $0270-6474 / 99 / 195619-13 \$ 05.00 / 0$
}

In hippocampal slices, studies in area CA1 indicate that BDNF can potentiate excitatory transmission, probably by a presynaptic mechanism that is mediated by trkB (Kang and Schuman, 1995; Takei et al., 1997; Gottschalk et al., 1998). In area CA3, this also appears to be the case (Scharfman, 1997). In addition, there was a striking afferent specificity in CA3, because bath application of BDNF led to potentiation of mossy fiber transmission but not other inputs (Scharfman, 1997). Furthermore, regional specificity was apparent, because granule cell responses to perforant path stimulation were relatively unaffected by bath-applied BDNF. This apparent specificity was interesting in light of the fact that the mossy fibers are strongly immunoreactive to BDNF antisera relative to other afferents (Conner et al., 1997; Yan et al., 1997). Indeed, of all the fiber systems in the forebrain, BDNF expression is perhaps greatest in the mossy fibers (Conner et al., 1997; Yan et al., 1997).

To probe further the apparent preferential effect of BDNF on mossy fibers, we made use of a widely known animal model of epilepsy in which the muscarinic agonist pilocarpine induces status epilepticus. This is followed after $\sim 1-2$ weeks by reorganization of the mossy fibers (Mello et al., 1993). The reorganized mossy fibers innervate novel target neurons, including the granule cells (Okazaki et al., 1995; Kotti et al., 1997). We hypothesized that if BDNF's effects were specific for mossy fibers, then responses of granule cells to their new mossy fiber input would be enhanced by BDNF. This model had further utility because it allowed us to examine the effects of BDNF in hippocampus after seizures, when BDNF and trkB mRNA and protein increase 
(Ballarin et al., 1991; Ernfors et al., 1991; Isackson et al., 1991; Gall, 1993; Humpel et al., 1993; Nibuya et al., 1995; Mudò et al., 1996; Schmidt-Kastner et al., 1996; Rudge et al., 1998).

\section{MATERIALS AND METHODS}

Animal care was consistent with the guidelines set by the New York State Department of Health and National Institutes of Health. Adult male Sprague Dawley rats (190-250 gm) were treated with pilocarpine (see below) and examined electrophysiologically 2-9 months later. All chemicals were obtained from Sigma (St. Louis, MO) unless stated otherwise.

Pilocarpine treatment. Before pilocarpine treatment, rats were injected with atropine methylbromide $(1 \mathrm{mg} / \mathrm{kg}$, s.c.). After $30 \mathrm{~min}$ they were injected with pilocarpine hydrochloride $(380 \mathrm{mg} / \mathrm{kg}$, i.p.). Most of these animals subsequently had seizures and status epilepticus, defined as continuous stage 3-5 seizures (Racine, 1972). Animals with status for 1 $\mathrm{hr}$ were treated with diazepam $(5 \mathrm{mg} / \mathrm{kg}$, i.p.) (Wyeth-Ayerst).

Preparation and maintenance of slices. Animals were anesthetized with ether and decapitated. The brain was immersed in ice-cold sucrose buffer and cut horizontally into $400 \mu \mathrm{m}$ slices using a Vibroslice (Campden Instruments). Immediately after dissection, slices were transferred to a modified interface chamber (Fine Science Tools), where they were placed on a nylon net, perfused with sucrose buffer so that they were semisubmerged, warmed to $32-33^{\circ} \mathrm{C}$, and oxygenated $\left(95 \% \mathrm{O}_{2}, 5 \%\right.$ $\mathrm{CO}_{2}$ ). Sucrose buffer was used as the buffer until $30 \mathrm{~min}$ after the dissection. After that time, a NaCl-based buffer was used to perfuse the slices. Sucrose buffer contained (in mM): 125 sucrose, $5 \mathrm{KCl}, 2.0 \mathrm{CaCl}_{2}$, $2.0 \mathrm{MgSO}_{4}, 26 \mathrm{NaHCO}_{3}, 1.25 \mathrm{NaH}_{2} \mathrm{PO}_{4}$, and 10 D-glucose, $\mathrm{pH}$ 7.4. The $\mathrm{NaCl}$-based buffer contained the same constituents except that $\mathrm{NaCl}$ was substituted equimolar for sucrose.

Recording and stimulation. Recordings were made after slices had been perfused with NaCl-based buffer for at least $30 \mathrm{~min}$. Extracellular and intracellular recording electrodes were pulled horizontally (Model P87, Sutter Instruments) from borosilicate glass with a capillary fiber in the lumen $(1.0 \mathrm{~mm}$ outer diameter, $0.75 \mathrm{~mm}$ inner diameter; World Precision Instruments). Extracellular electrodes were filled with the NaCl-based buffer (see preceding paragraph) and resistances were 5-10 $\mathrm{M} \Omega$. Intracellular electrodes were filled with $1 \mathrm{~m}$ potassium acetate, and their resistances ranged between 50 and $100 \mathrm{M} \Omega$. An intracellular amplifier with a bridge circuit was used for recordings (Axoclamp 2B, Axon Instruments), and the bridge was balanced whenever current was passed through the intracellular recording electrode. Data were digitized and saved on tape (Neurocorder DR-484, Neurodata Instruments) or disk (Pro10, Nicolet Instruments) and plotted off-line (Model HC100, Tektronix).

The mossy fibers were stimulated by a $75 \mu \mathrm{m}$ Teflon-coated stainless steel wire placed on the slice surface in the center of the hilus, at the end of the CA3c pyramidal cell layer. Rectangular pulses $(5-150 \mu \mathrm{A}, 10 \mu \mathrm{sec}$, $0.05 \mathrm{~Hz}$ ) were used to evoke responses. To stimulate the perforant path, the stimulating electrode was placed at the fissure, just below the subiculum. Recordings sites from different dentate gyrus lamina listed in Results were located as follows: (1) hilar recording sites were 100-150 $\mu \mathrm{m}$ from the granule cell layer/hilus border; (2) sites in the granule cell layer were in the middle of that layer; (3) inner molecular layer sites were $50 \mu \mathrm{m}$ from the granule cell layer/inner molecular layer border; (4) middle molecular layer sites were $150 \mu \mathrm{m}$ from the cell layer/inner molecular layer border; and (5) outer molecular layer sites were 50-100 $\mu \mathrm{m}$ from the hippocampal fissure. Measurements were made with an ocular micrometer.

Drug application. BDNF was generously provided by Regeneron Pharmaceuticals (Tarrytown, NY). It was diluted in $0.01 \%$ bovine serum albumin (BSA) in sterile PBS (Life Technologies) to make a stock solution of $100 \mu \mathrm{g} / \mathrm{ml}$ and was refrigerated until use. Stock solutions (10 $\mathrm{mM}$ ) of D-amino phosphonovaleric acid (D-APV) and bicuculline methiodide were made in $0.9 \% \mathrm{NaCl}$ and frozen until the day of the experiment. Aliquots were added to the buffer to reach the following final concentrations: BDNF $(50-200 \mathrm{ng} / \mathrm{ml})$, heat-inactivated BDNF $(200 \mathrm{ng} / \mathrm{ml})$, D-APV $(50 \mu \mathrm{M})$, or bicuculline methiodide $(10 \mu \mathrm{M})$. K252a (Alexis) was dissolved in $0.01 \%$ DMSO to produce a concentrated stock solution (10 $\mathrm{mM}$ ) and then diluted to reach a final concentration of $1 \mu \mathrm{M}$.

Isolation of the dentate gyrus. To sever connections of the dentate gyrus with the entorhinal cortex and area CA3, cuts were made with a pair of dura scissors (Fine Science Tools). In these experiments, slices were first exposed to BDNF, and spontaneous bursts were recorded subsequently. Immediately thereafter the inflow to the chamber was increased so that slices were lifted slightly from the nylon mesh where they normally lie. One blade of the scissors was placed below the slice, and the other blade was above the slice. A cut was made across the "mouth" of the dentate gyrus (from the lateral tip of the upper blade to the lateral tip of the lower blade), severing the pyramidal cell layer at the CA3b and CA3c border and surrounding strata. Another cut was made through the subiculum, very close to the hippocampal fissure, at an angle that was approximately parallel to the first cut. It extended from the pia surface of the subiculum to stratum radiatum of area CA1.

Anatomy. Sprouting was determined by staining the dentate gyrus either with a polyclonal antibody to neuropeptide $\mathrm{Y}$ or by the Timm method (Sloviter, 1982). In some animals, alternate sections were stained with the Timm method and an antibody to BDNF, which was generously provided by Regeneron Pharmaceuticals (Tarrytown, NY).

For neuropeptide $\mathrm{Y}$ staining, slices were removed from the recording chamber after the experiment and were immersion-fixed in $4 \%$ paraformaldehyde. They were resectioned at $50 \mu \mathrm{m}$ as described previously (Scharfman, 1995). Immunocytochemistry followed a procedure that has been reported by Sloviter (1991). Briefly, free-floating sections were washed in $0.1 \mathrm{M}$ Tris buffer, $\mathrm{pH}$ 7.6, followed by incubation in $1 \% \mathrm{H}_{2} \mathrm{O}_{2}$ (dissolved in Tris) for $30 \mathrm{~min}$. After a $5 \mathrm{~min}$ wash in Tris, sections were washed in Tris containing $0.1 \%$ Triton $\mathrm{X}-100$ (Tris A) for $15 \mathrm{~min}$, followed by a 15 min wash in Tris A containing $0.005 \%$ BSA (Tris B). The sections were incubated overnight at $4^{\circ} \mathrm{C}$ in antisera to neuropeptide Y (1:2000; Peninsula), diluted in Tris B. On the second day, sections were washed for $15 \mathrm{~min}$ in Tris A followed by $15 \mathrm{~min}$ in Tris B. The sections were then incubated for $45 \mathrm{~min}$ in biotinylated Protein A (1:300; Vector), diluted in Tris B. After a 15 min wash in Tris A and a 15 min wash in Tris $\mathrm{D}(0.5 \mathrm{~m}$ Tris containing $0.1 \%$ Triton and $0.005 \%$ BSA), sections were incubated for $1 \mathrm{hr}$ in avidin-biotin-horseradish peroxidase complex (ABC, 1:1000 dilution; Elite kit, Vector) diluted in Tris D. Sections were washed in Tris (three times for 5 min each) and developed in diaminobenzidine tetrahydrochloride (DAB) $(50 \mathrm{mg} / 100 \mathrm{ml}$ Tris, Polysciences) plus $200 \mathrm{mg} \beta$-D-glucose, $0.3 \mathrm{mg}$ glucose oxidase, and $40 \mathrm{mg}$ ammonium chloride. Sections were mounted on slides, dehydrated in a series of graded ethanol solutions, and coverslipped with Permount (Fisher).

For Timm and BDNF staining, rats were anesthetized with ether (J.T. Baker) followed by urethane (1.25 gm/ kg, i.p.) and perfused as follows: saline (3 $\mathrm{min}), 0.37 \%$ sulfide solution, $\mathrm{pH} 7.2$ (5 min), saline ( $2 \mathrm{~min}), 2 \%$ paraformaldehyde in $0.1 \mathrm{~m}$ borate buffer, $\mathrm{pH} 6.5$ (3 min), $2 \%$ paraformaldehyde $/ 0.1 \%$ glutaraldehyde in $0.1 \mathrm{M}$ borate buffer, $\mathrm{pH} 8.5$ (15 min). Alternate sections were used for Timm or BDNF staining. Sections for BDNF immunocytochemistry were treated as for neuropeptide $\mathrm{Y}$, except that the $\mathrm{H}_{2} \mathrm{O}_{2}$ concentration was $0.5 \%$, Triton/BSA was $1 \% / 0.005 \%$, and goat anti-rabbit (1:400, Vector) was used instead of protein A. In addition, immediately before incubation with primary antibody, sections were washed in Tris A (15 min) and Tris D (15 min) and incubated with $10 \%$ normal goat serum dissolved in Tris B. BDNF antisera was diluted 1:15,000, and staining was intensified with $50 \mathrm{~mm} \mathrm{NiNH}_{3} \mathrm{SO}_{4}$.

\section{RESULTS}

\section{Mossy fiber sprouting in pilocarpine-treated rats}

There were two groups of animals used for this study. The first group included those rats that had status epilepticus (defined as continuous behavioral seizures) for $1 \mathrm{hr}$ immediately after pilocarpine injection. A few weeks later, these animals began to have spontaneous behavioral seizures (stage 4-5) intermittently. All of these animals demonstrated mossy fiber sprouting $(n=20)$ (Fig. 1A).

The second group included animals that were injected with pilocarpine but did not develop status epilepticus. These animals had mild, intermittent seizures (stages 1-2) immediately after pilocarpine administration, but never progressed to more severe seizures or status epilepticus. There were no behavioral seizures observed in this group in subsequent weeks. The animals within this group could not be distinguished in terms of sprouting (there was no mossy fiber sprouting) (Fig. $1 B$ ) and effects of BDNF (there were no effects on evoked responses of granule cells), and therefore the data from these animals were pooled $(n=8)$.

Sprouting was determined by immunocytochemistry using an 

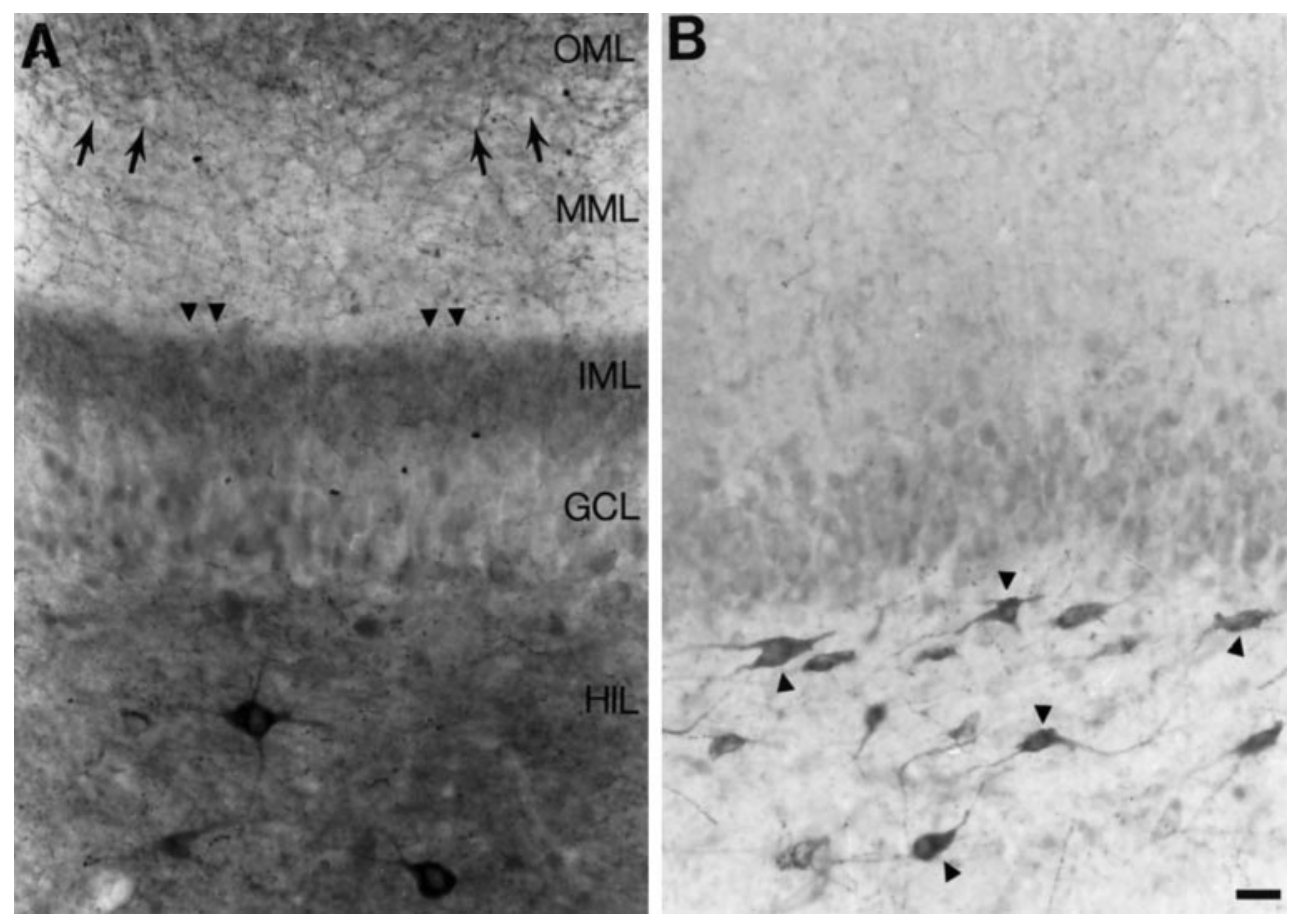

Figure 1. Mossy fiber sprouting in slices from pilocarpine-treated rats. $A$, A section of a hippocampal slice from a rat that developed status epilepticus after pilocarpine treatment illustrates mossy fiber sprouting as a band of neuropeptide $\mathrm{Y}$ staining in the inner molecular layer (arrowheads). Note that there also is staining of fibers in the outer molecular layer (small arrows). A few neuropeptide Y-immunoreactive neurons are in the hilus. Scale bar (shown in $B$ ): $35 \mu \mathrm{m}$. The positions of the layers correspond to both $A$ and $B$ and are abbreviated as follows: $G C L$, granule cell layer; $H I L$, hilus; $I M L$, inner molecular layer; $M M L$, middle molecular layer; $O M L$, outer molecular layer. $B$, A section from a hippocampal slice of a rat that did not develop mossy fiber sprouting illustrates the normal pattern of neuropeptide Y-like immunoreactivity in the dentate gyrus. Many hilar neurons are stained (arrowheads). Some staining in the outer molecular layer is also normal. There is some staining of granule cells in this section, because it was incubated in $\mathrm{DAB}$ for an extended period of time. This was done to increase the likelihood that sprouted fibers would be detectable, if in fact they were present. However, there was no evidence that there was neuropeptide Y-immunoreactive sprouting in this section or in our other control sections.

antibody to neuropeptide Y, which marks mossy fibers after seizures (Gall et al., 1990; Sperk et al., 1992, 1996; Gruber et al., 1994; Chafetz et al., 1995; Vezzani et al., 1996; Lurton and Cavalheiro, 1997). Sprouting was evident as a band of neuropeptide Y-immunoreactive fibers in the inner molecular layer (Fig. 1A).

In rats without sprouting, neuropeptide $\mathrm{Y}$ staining in the dentate gyrus was present, but this was confined to some fibers in the outer molecular layer and some hilar neurons, as has been described previously for normal rats (Köhler et al., 1986; Deller and Leranth, 1990; Milner and Veznedaroglu, 1992). To ensure that sprouting would be detected if it were present, incubation of sections with DAB (see Materials and Methods) was prolonged until background staining was significant (Fig. 1B), i.e., granule cells began to stain. Even after this procedure, sprouting in the inner molecular layer was not evident (Fig. 1B).

Timm staining was also used to detect sprouting in a separate group of animals that were perfusion-fixed $(n=4)$. In all cases in which Timm staining illustrated sprouting (see Fig. 9B), neuropeptide $\mathrm{Y}$ staining also demonstrated sprouting. Conversely, when there was no evidence of sprouting with neuropeptide Y immunohistochemistry, sprouting was not detected by Timm stain either.

Neuropeptide Y staining was examined not only in slices after recordings were made but also in tissue that had not been recorded. This enabled us to determine whether some sprouting that actually was present had been missed because neuropeptide Y staining in recorded slices was not optimal. Suboptimal staining could occur for a number of reasons related to slicing, such as degradation of antigenicity while slices were in the recording chamber. The results showed that immunoreactivity for neuropeptide $\mathrm{Y}$ in sections from the slices that had been recorded was indistinguishable from the sections of the same animal that had not been exposed to recording conditions (data not shown).
Thus, recording conditions did not appear to impair the ability of neuropeptide Y immunocytochemistry to detect mossy fiber sprouting.

\section{Effects of BDNF in pilocarpine-treated rats}

Effects of BDNF were tested in 60 hippocampal slices from 14 pilocarpine rats that were killed 2-9 months after pilocarpine injection. The large number of slices per animal was possible because up to 10 slices could be placed on the netting over the recording well of our chamber at one time. Electrophysiology was performed blind to whether there was mossy fiber sprouting, and immunocytochemistry was conducted blind to the physiological data.

\section{Effects of BDNF on granule cell activation and spontaneous activity}

Responses to hilar stimulation in slices with and without sprouting. Hilar stimulation in slices from pilocarpine-treated rats with sprouting $(n=34)$ evoked an antidromic population spike, followed by a second population spike in most cases (23/34) (Fig. $2 A$ ). The maximum amplitude of the second population spike was $6 \mathrm{mV}$. When no sprouting occurred, an antidromic population spike was evoked by hilar stimulation, but there was no second population spike (Fig. $2 B$ ). There was instead an afterpotential (negative or positive) that was never larger than $1 \mathrm{mV}$ and lasted $>20 \mathrm{msec}$. Stimulus strength for these experiments was set at an intensity that produced a half-maximum antidromic spike.

Only one population spike was evoked by perforant path stimulation in the same slices where two spikes were evoked by hilar stimulation (tested in 20 of the 34 slices) (see Fig. $5 A$ ), indicating that the hilar-evoked second population spike was not necessarily caused by the use of unhealthy slices with weak inhibition. Rather, it could reflect the ability of hilar stimulation to activate recurrent 


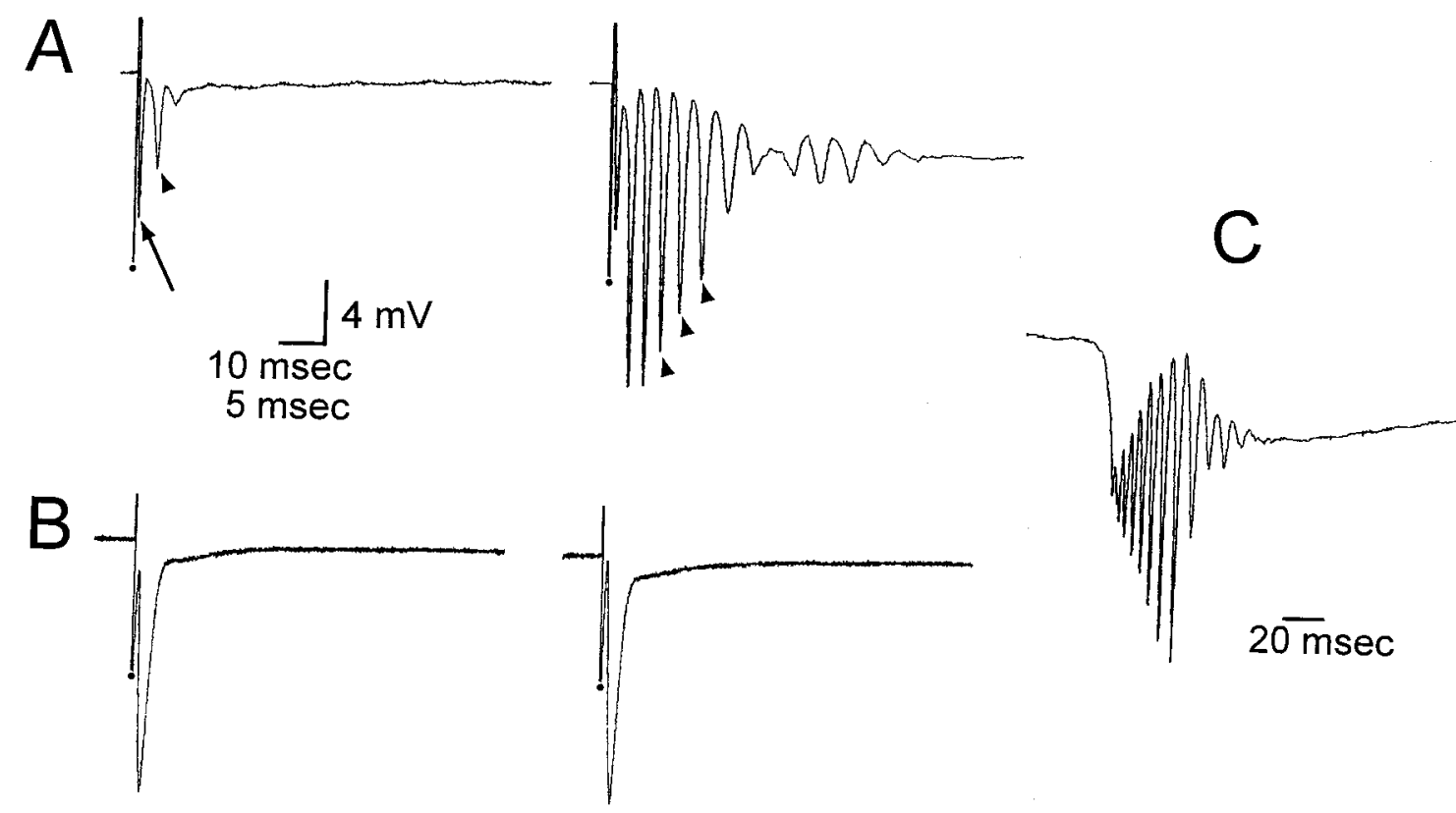

Figure 2. Effects of BDNF on hilar-evoked responses of granule cells in slices with or without mossy fiber sprouting. $A$, In a rat that had mossy fiber sprouting, a hilar stimulus evoked two population spikes in the granule cell layer before BDNF application. The population spike with the shortest latency (arrow) was likely to be antidromic because it immediately followed the stimulus, and the later spike (arrowhead) was likely to be caused by mossy fiber collaterals that activated granule cells, because it was never present in slices without sprouting (see $B$ ). The orthodromic population spike increased in amplitude after exposure to BDNF (200 ng/ml, $45 \mathrm{~min}$ ), and secondary population spikes developed (arrowheads). Stimulus artifacts are marked by dots and are truncated. Calibration: $4 \mathrm{mV}, 10 \mathrm{msec} . B$, In a rat that was treated with pilocarpine but did not have mossy fiber sprouting, a stimulus to the hilus evoked an antidromic spike, and this was unchanged after perfusion with BDNF for $1 \mathrm{hr}$. Note change in time base compared with $A$. Calibration (shown in $A$ ): $4 \mathrm{mV}, 5 \mathrm{msec}$. $C$, In the same slice as $A$, spontaneous bursts of population spikes occurred after BDNF. Voltage calibration shown in $A$.

excitatory collaterals of mossy fibers. This has been indicated in previous studies of sprouting after kainic acid treatment (Tauck and Nadler, 1985).

Effects of BDNF on responses to hilar stimulation. In slices where sprouting occurred, perfusion with BDNF (50 ng/ml, $n=3 ; 200$ $\mathrm{ng} / \mathrm{ml}, n=10$ ) for $30-60 \mathrm{~min}$ had no detectable effect on the amplitude of the antidromic spike recorded in the granule cell layer, but numerous population spikes developed (at least four) (Fig. 2A). Perfusion with heat-inactivated BDNF (200 ng $/ \mathrm{ml}, n=$ 5 ) had no effect on the antidromic or orthodromic population spike. In contrast to slices with sprouting, there were no effects of BDNF on hilar-evoked responses in slices without sprouting (200 $\mathrm{ng} / \mathrm{ml}, n=6)$.

Spontaneous activity. After 30-60 min of BDNF exposure, bursts of spontaneous population spikes occurred in the granule cell layer of sprouted slices ( $n=32 / 34$ slices) (Fig. $2 C$ ). These bursts occurred in slices that were intermittently stimulated at low frequency, as well as in others that were never stimulated at all ( $n=24 / 24$ tested), and hence were unlikely to be attributable to the history of previous electrical stimulation. Bursts occurred at variable frequency $(0.05-0.5 \mathrm{~Hz})$. No spontaneous population spikes ever occurred in slices without sprouting that were exposed to $\mathrm{BDNF}$, even after $3 \mathrm{hr}$ of bath application. Intracellular recordings from granule cells $(n=10)$ demonstrated that granule cells discharged during the spontaneous bursts that were recorded extracellularly (Fig. $3 A$ ). In Figure $3 A$, a brief period of afterdischarges also occurred after the initial period of discharge, and this was evident in the extracellular recording as a second, smaller spontaneous potential. The number of primary and secondary discharges varied from slice to slice, with more occurring in ventral slices (see Fig. 8). This may be because of the fact that the ventral hippocampus is different from the dorsal hippocampus, or the fact that there was heavier sprouting in our ventral slices.

In the two (of the total 34) slices in which there was no spontaneous activity after BDNF, despite robust sprouting, evoked responses were similar in amplitude to those recorded in other slices, so deterioration of the slice was not a likely reason for the lack of effect of BDNF. Rather, it is possible that the effects of BDNF on granule cells in sprouted rats are similar to the effects of BDNF in normal rats, in which BDNF does not have an effect in all neurons or slices tested (Carmignoto et al., 1997; Scharfman, 1997).

Specificity of BDNF's effects for synapses in the inner molecular layer. Laminar profiles of evoked or spontaneous bursts demonstrated that the underlying negative envelope of the burst, presumably reflecting the underlying depolarization or EPSP, was maximal in the inner molecular layer, and reversed polarity in the middle and outer molecular layers (Fig. 3B). The amplitude of the extracellularly recorded burst events decreased as the recording electrode was moved even further from the molecular layer (i.e., either across the hippocampal fissure, toward CA1, or from the granule cell layer into the hilus and the CA3 pyramidal cell layer).

Evoked responses to hilar stimulation that were recorded in the inner molecular in slices with sprouting consisted of a shortlatency, rapid potential, followed by a slower, negative potential (Fig. 4). The short-latency potential probably represented a fiber volley (caused by activation of mossy fiber axons located nearby) or antidromic population spike (volume-conducted from the adjacent cell layer). The amplitude of the short-latency potential (measured from baseline to peak) did not change significantly after BDNF treatment $(200 \mathrm{ng} / \mathrm{ml}$, increase to $119 \pm 11 \%$ of control, $n=7$ ) (Fig. 4). 

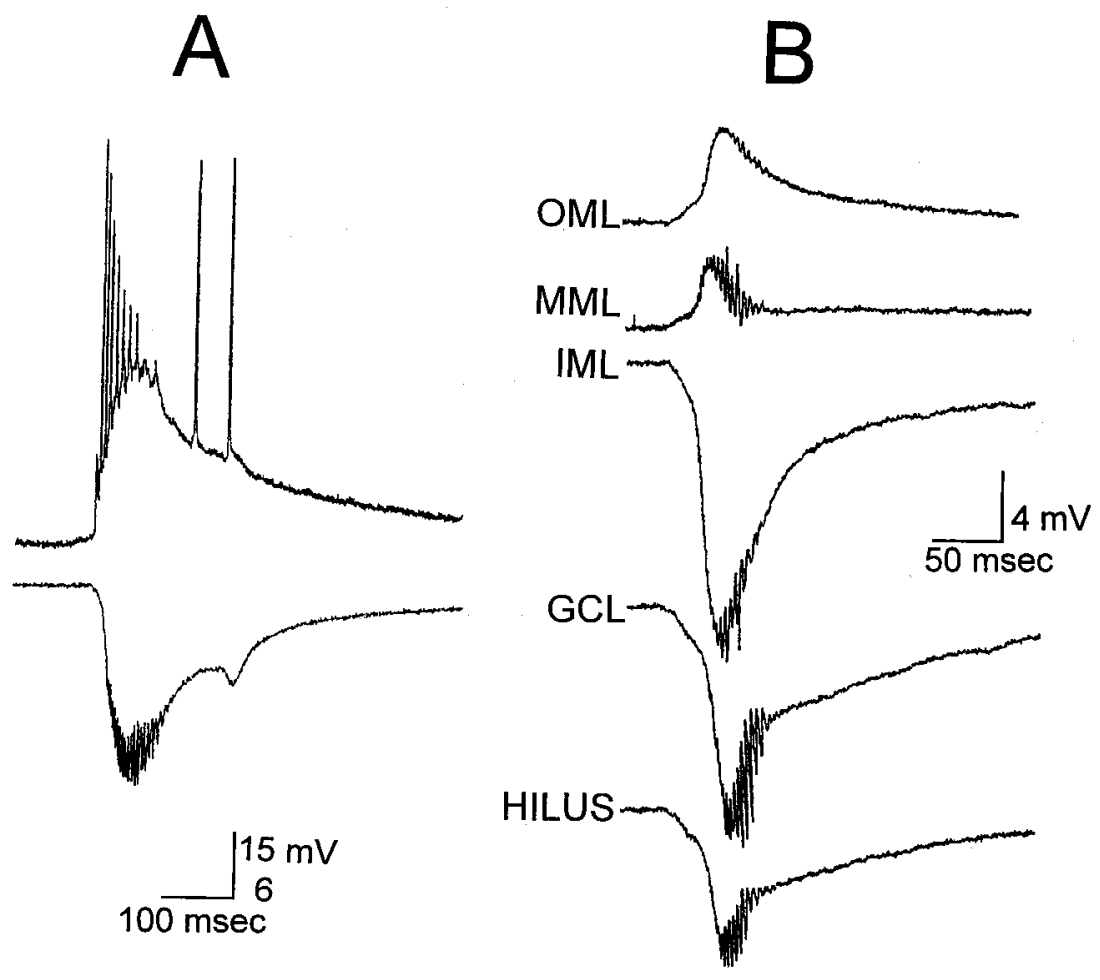

Figure 3. Spontaneous activity of granule cells after exposure to BDNF. $A$, Simultaneous intracellular and extracellular recordings, 70 min after BDNF bath application. Intracellular recording from a granule cell (top) illustrates that it discharged spontaneously during the field potential recorded in the inner molecular layer (bottom). B, Laminar profile of spontaneous granule cell bursts, 60 min after the onset of BDNF exposure $(200$ $\mathrm{ng} / \mathrm{ml}$ ), in a different slice from $A$. This slice was never stimulated, ruling out the possibility that this activity was stimulus-induced. Recordings were made of consecutive spontaneous bursts, which occurred every 6-10 sec. $O M L$, Outer molecular layer, where the spontaneous activity was the reverse polarity of that in the inner molecular layer; $M M L$, middle molecular layer; $I M L$, inner molecular layer, where the largest field potential was recorded; $G C L$, granule cell layer, where the largest population spikes were recorded; HILUS, $100 \mu \mathrm{m}$ from the granule cell layer in the hilus, where the spontaneous activity was smaller than in the granule cell layer. As the recording electrode was moved farther from the granule cell layer, the spontaneous activity decreased in amplitude. There was no spontaneous activity detected in areas CA3 or CA1 or the entorhinal cortex of this slice.
The slower, negative potential that was recorded in the inner molecular layer in response to hilar stimulation was likely to be an extracellularly recorded EPSP because it was analogous in latency to perforant path-evoked EPSPs of normal rats that are recorded in the outer molecular layer, and because the potential was largest in the inner third of the molecular layer, where sprouted fibers terminate. The extracellularly recorded EPSP (measured from baseline to peak) increased in amplitude in five of seven slices after BDNF exposure $(200 \mathrm{ng} / \mathrm{ml}$; increase to $201 \pm 12 \%$ of control amplitude, $n=5$ ) (Fig. 4). In the other two slices there was no change in amplitude, even after $60 \mathrm{~min}$ of perfusion with BDNF.

These data indicated that spontaneous and evoked bursts were likely to be due to the effects of BDNF on synaptic responses that were generated in the inner molecular layer, where sprouted fibers terminate. However, the trigger for spontaneous bursts
Figure 4. BDNF increases the extracellularly recorded EPSP in the inner molecular layer of sprouted rats in response to mossy fiber stimulation. Extracellular recordings were made from the inner molecular layer in response to a hilar stimulus in a slice with mossy fiber sprouting. The response was composed of a short-latency fiber volley ( $a r$ rowhead) and longer-latency field EPSP (arrow $)$. After BDNF (200 ng/ml) was bathapplied, the fiber volley remained unchanged but the field EPSP increased in amplitude. The times shown are the times after the start of BDNF bath application when the responses were evoked.
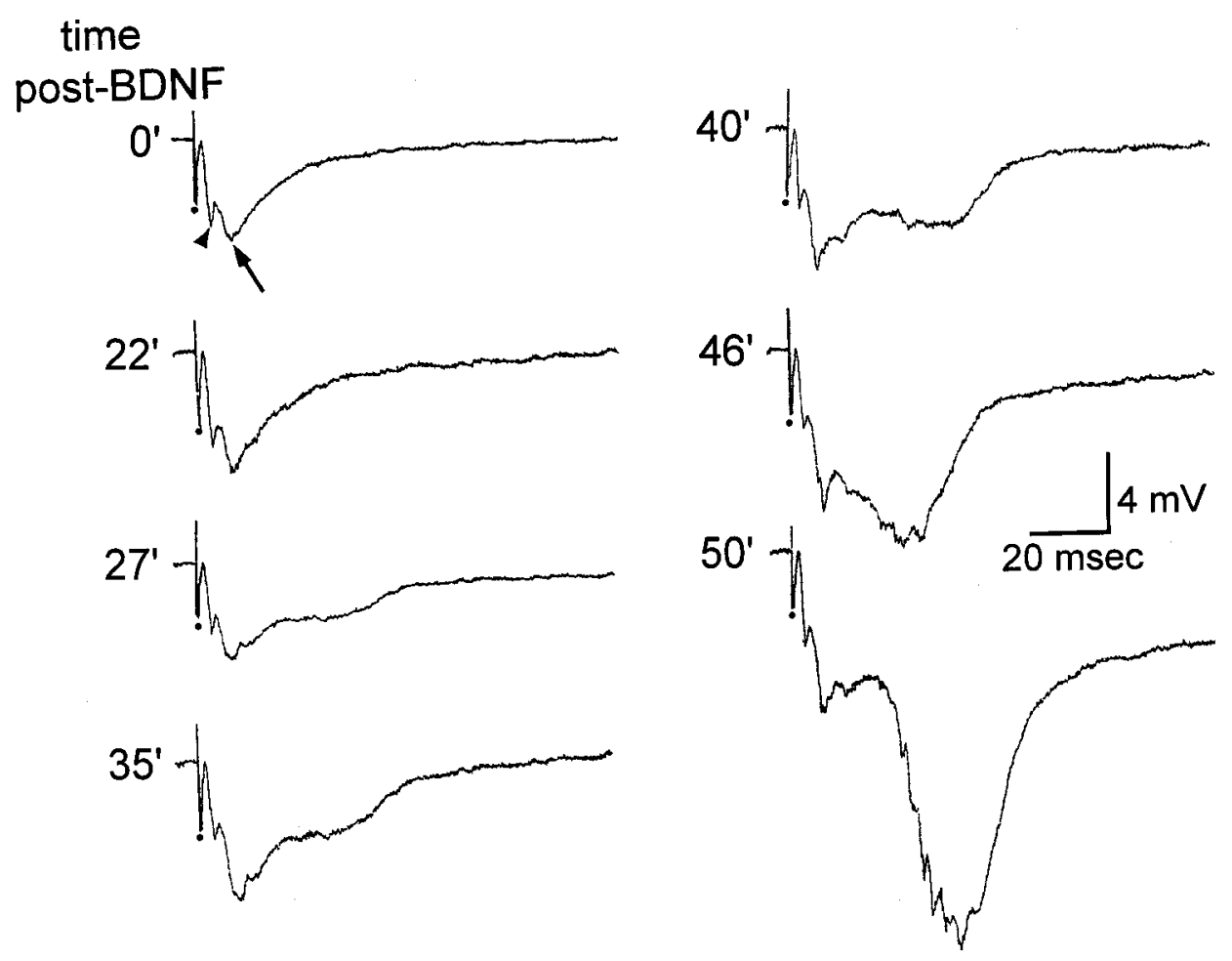


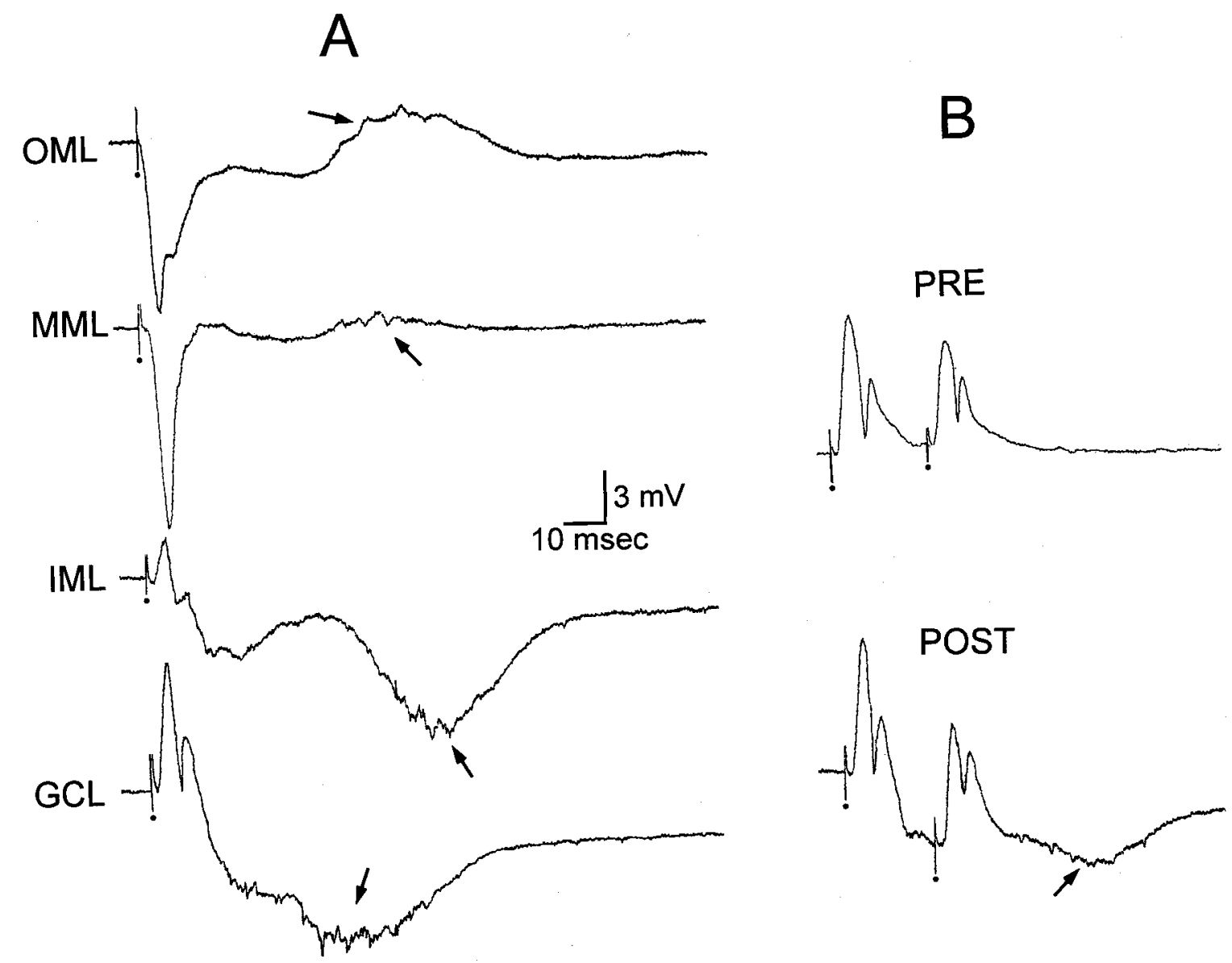

Figure 5. Paired-pulse inhibition before and after BDNF. A, A single stimulus to the molecular layer of a slice with mossy fiber sprouting, after BDNF bath application, was recorded in several layers of the dentate gyrus. Each stimulus was identical. The stimulus evoked a response at an early latency that was similar to slices without sprouting. However, at a long latency another event occurred (arrow). Given the long latency, all-or-none nature, and the fact that this potential reversed in the middle molecular layer, it is likely that it represents enhanced activity in the sprouted network after BDNF (compare with Fig. 3B). $O M L$, Outer molecular layer; $M M L$, middle molecular layer; $I M L$, inner molecular layer; $G C L$, granule cell layer. $B$, Extracellularly recorded responses to outer molecular layer stimulation were made in the granule cell layer before BDNF application (PRE). The responses to the same stimuli were tested again after BDNF bath application (POST; $200 \mathrm{ng} / \mathrm{ml}, 45 \mathrm{~min}$ ). After BDNF, the population spikes were similar, but the stimuli evoked an additional slow potential on which the population spikes were superimposed (arrow). The slow potential could be detected better after responses to single stimuli (see $A$ ), because the event began at a relatively long latency. Calibration same as in $A$.

could lie within or outside the dentate gyrus. The entorhinal input (the perforant path) and the CA3 pyramidal cell projection to the dentate gyrus are two possibilities. The possibility was further evaluated by isolating the dentate gyrus from the entorhinal cortex and area CA3 using cuts through the slice. In four slices where cuts were made (at the hippocampal fissure, to sever perforant path fibers, and across $\mathrm{CA} 3 \mathrm{~b} / \mathrm{c}$, to sever CA3 projections to the dentate; see Materials and Methods), there was no detectable change in spontaneous activity in the dentate gyrus. Burst duration (mean, $259 \pm 84 \mathrm{msec}$ before vs $255 \pm 89 \mathrm{msec}$ after the cuts) and burst frequency $(0.14 \pm 0.06 \mathrm{~Hz}$ before vs $0.16 \pm 0.06$ after) were maintained (paired $t$ tests, $p>0.05$ ). The results suggest that the spontaneous activity occurring after BDNF application was generated within the dentate gyrus.

Molecular layer stimulation. In slices with sprouting that had been exposed to BDNF, there was no significant change in mean amplitude of the granule cell population spike recorded in the granule cell layer $(n=4)$ in response to stimulation of the outer molecular layer (Fig. 5A). Maximum population spike amplitude was $1.0 \pm 0.5 \mathrm{mV}$ before and $1.5 \pm 0.7 \mathrm{mV}$ after $60 \mathrm{~min}$ perfusion with $200 \mathrm{ng} / \mathrm{ml}$ BDNF ( $n=6$, paired $t$ test, $p>0.05$ ). In three of the six experiments, no population spike could be evoked by stimulation of the outer molecular layer (thus amplitude was 0 in these experiments), and this did not change after BDNF was applied. Presumably these small responses were due to the loss of the cells of origin of the perforant path in the superficial layers of the entorhinal cortex after status epilepticus (Du et al., 1995), which we confirmed by Nissl stain (data not shown). Thus, in only one of six slices was there an increase in population spike amplitude after BDNF exposure.

As shown in Figure $5 A$, after BDNF application and the associated spontaneous activity of granule cells developed, molecular layer stimulation evoked a long-latency extracellular burst discharge that was similar in some ways to the relatively shortlatency burst discharges evoked by hilar stimulation. That is, the molecular layer-evoked burst discharge was an all-or-none event that reversed polarity in the middle molecular layer (Fig. 5A). These characteristics suggest that molecular layer-evoked bursts could be due to activation of mossy fibers of granule cells subsequent to perforant path activation. 

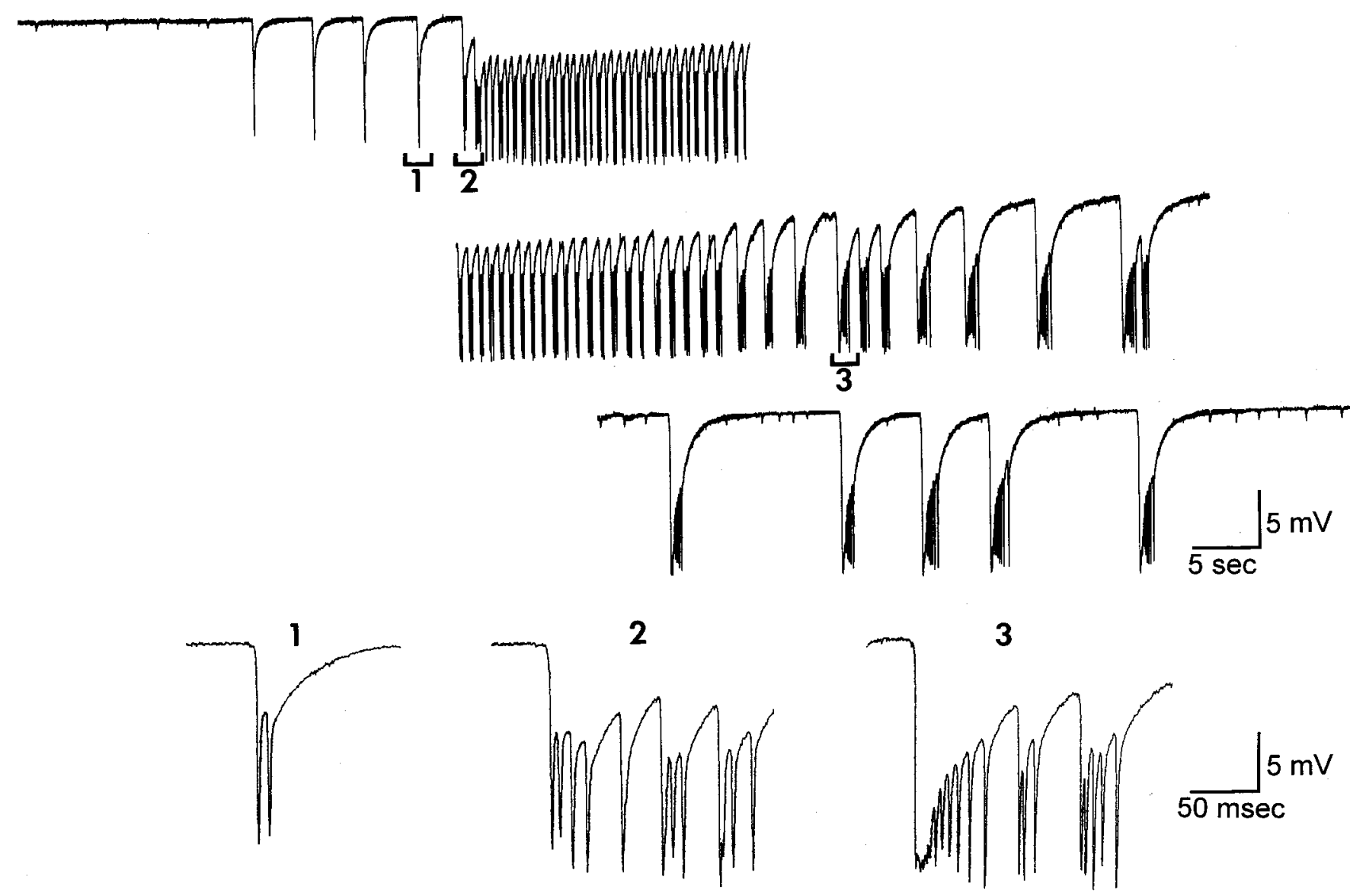

Figure 6. Effects of BDNF and bicuculline in slices with mossy fiber sprouting. A spontaneous seizure-like event is illustrated that occurred after bath-application of BDNF (200 ng/ml, $60 \mathrm{~min})$ and bicuculline $(10 \mu \mathrm{M})$. Bicuculline was present only for the last $10 \mathrm{~min}$ of the $60 \mathrm{~min}$ period of BDNF perfusion. The seizure-like episode began with periodic brief discharges (1), and a paroxysmal period followed (the start of this period is indicated by 2). The paroxysmal period was followed by a series of afterdischarges (e.g., 3).

\section{Pharmacology}

Effects of BDNF on GABAergic inhibition. Although it has been proposed that BDNF enhances excitatory transmission by increasing glutamate release, there also is evidence that BDNF acts by decreasing GABA receptor-mediated inhibition [Tanaka et al. (1997); also see Kim et al. (1994)]. Therefore, paired-pulse inhibition of granule cell population spikes was monitored before and after BDNF. Population spikes were evoked by molecular layer stimulation, and a $20 \mathrm{msec}$ interstimulus interval was used (Fig. $5 B)$, because this paradigm ordinarily evokes strong inhibition that is dependent on GABA receptors.

Paired-pulse inhibition was present before and after BDNF application. The maximal population spike was inhibited by $83 \pm$ $9 \%$ by a stimulus $20 \mathrm{msec}$ before the test stimulus $(n=3)$ before BDNF application, and $60 \mathrm{~min}$ after BDNF application this value was $88 \pm 12 \%$. This change was not significant (paired $t$ test, $p>$ 0.05 ). There were spontaneous discharges of granule cells at the time when paired-pulse inhibition had not changed, so the lack of effect was not because BDNF had no effect in these slices.

Although these results argue against the possibility that BDNF led to disinhibition by blocking GABA receptors or impairing GABAergic function, one potential confound is that the cells of origin of the perforant path (entorhinal cortical neurons) were damaged by pilocarpine. If the pathway had not been affected by pilocarpine, a change in paired-pulse inhibition might have been evident.
Another way to test whether BDNF acted by blocking GABAergic inhibition is to determine whether BDNF occluded the effects of a $\mathrm{GABA}_{\mathrm{A}}$ receptor antagonist, such as bicuculline (Fig. 6). Therefore, we tested whether there was an effect of bicuculline after BDNF application, and specifically after BDNF had already produced its effects. In those slices $(n=18)$, bicuculline enhanced the effects of BDNF in that burst discharges of granule cells became prolonged. This effect occurred within minutes of exposure to bicuculline, unlike the effects of BDNF, which required $>30 \mathrm{~min}$. The prolonged episodes were seizure-like in that they had a paroxysmal component followed by afterdischarges (Fig. 6A). The paroxysmal component lasted up to $1 \mathrm{~min}$, and the period of subsequent afterdischarges lasted up to $2 \mathrm{~min}$. These episodes were separated by 1-3 min and were repetitive for at least $1 \mathrm{hr}$. Each episode was heralded by a series of spontaneous, brief discharges (Fig. $6 B, 1$ ) that suddenly became paroxysmal (Fig. $6 B, 2)$. The prolonged events, like the brief discharges, were maximal in the inner molecular layer and reversed polarity in the middle and outer molecular layers (Fig. 7), suggesting that their site of generation was similar to the brief discharges that occurred before bicuculline was added. These data support the interpretation of results described above that BDNF acted preferentially at mossy fibers in the inner molecular layer.

Bicuculline and BDNF had similar effects regardless of the order in which they were bath-applied. When bicuculline was introduced first $(n=6)$, it rapidly increased the number of 


\section{GCL}

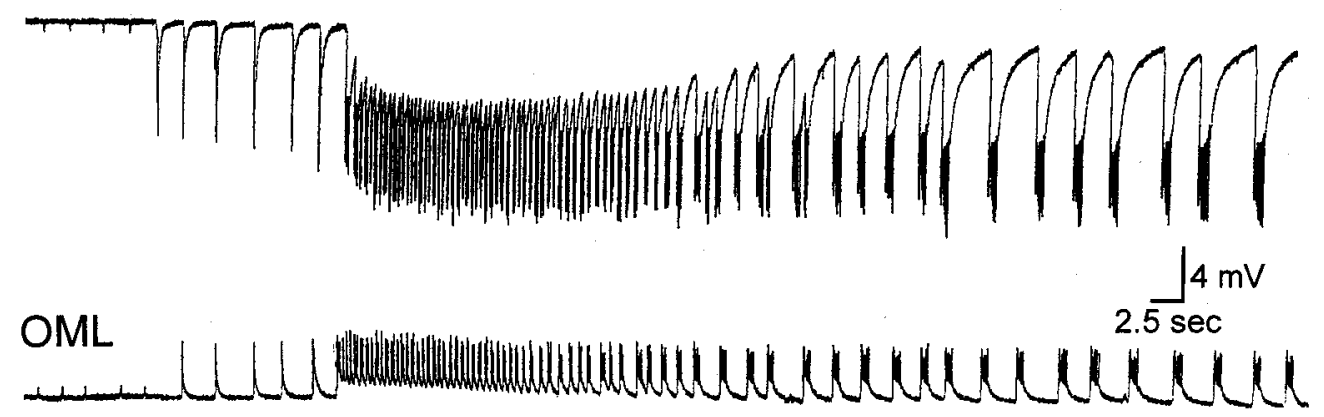

Figure 7. Reversal of epileptiform activity recorded in the presence of BDNF and bicuculline. A seizure-like episode was recorded from the granule cell layer $(G C L)$ in the same slice as Figure 6 . Note the different time base from Figure 6 . After $\sim 3$ min, another seizure-like episode was recorded from the same slice, but in the outer molecular layer $(O M L)$. The reversal of the extracellular recordings indicates that the seizure-like events reversed polarity in a similar area as the brief discharges produced by BDNF in the absence of bicuculline (Fig. 3). These data suggest that the site of origin of the spontaneous activity was in the inner/middle molecular layer, consistent with an underlying mechanism related to sprouted mossy fibers.

population spikes in response to mossy fiber stimulation, i.e., within minutes of bicuculline exposure. Spontaneous bursts of population spikes did not develop after bicuculline, except for three slices from the most ventral portion of the hippocampus with heavy sprouting. In these cases, burst discharges were similar in duration to those induced by BDNF (50-100 msec). Significantly, bicuculline application in the absence of BDNF never produced prolonged seizure-like events. Only after BDNF was subsequently added, in the continued presence of bicuculline, did this occur. The results suggest that the actions of $\mathrm{BDNF}$ were not mediated by a reduction of $\mathrm{GABA}_{\mathrm{A}}$ receptor-mediated inhibition, although some effect on GABAergic inhibition cannot be excluded entirely. A role of $\mathrm{GABA}_{\mathrm{B}}$ receptors in the actions of BDNF cannot be excluded either.

Protein kinases. To determine whether the actions of BDNF were mediated by a protein kinase, such as trkB, experiments were conducted in which slices were first incubated for $30 \mathrm{~min}$ with $\mathrm{K} 252 \mathrm{a}$ (at $1 \mu \mathrm{M}, \mathrm{K} 252 \mathrm{a}$ is a nonspecific kinase inhibitor), and then BDNF was applied in the continued presence of K252a. BDNF $(200 \mathrm{ng} / \mathrm{ml})$ did not have effects in these slices $(n=8)$, despite the fact that there was robust sprouting.

NMDA receptors. Recently there have been reports that BDNF has actions at NMDA receptors. In murine cultures and isolated hippocampal neurons, BDNF appeared to act as an agonist at the glycine site of the NMDA receptor (Jarvis et al., 1997). In hippocampal cultures, BDNF increased NMDA receptor open probability (Levine et al., 1998). Furthermore, it has been shown that BDNF induces phosphorylation of the NMDA receptor subunits 1 and 2B (Suen et al., 1997; Lin et al., 1998). Therefore, we tested whether the effects of BDNF in slices with sprouting were caused by increased activity at NMDA receptors (Fig. 8). Slices were pretreated with the NMDA receptor antagonist D-APV $(50 \mu \mathrm{M})$ for $30 \mathrm{~min}$, and subsequently BDNF was bathapplied $(200 \mathrm{ng} / \mathrm{ml})$ in the continued presence of D-APV. There was no detectable effect of D-APV in these experiments, which all exhibited spontaneous bursts of granule cells and had robust sprouting ( $n=6$; data not shown). In other experiments, BDNF was applied, and subsequently D-APV $(50 \mu \mathrm{M})$ was added in the continued presence of BDNF (200 $\mathrm{ng} / \mathrm{ml}$ ) (Fig. 8). In these experiments there also was no effect of D-APV $(n=3)$ (Fig. 8).

\section{BDNF immunocytochemistry}

These results may have implications for our understanding of how endogenous BDNF may function, because the mossy fibers of the normal rat contain one of the highest concentrations of BDNF in the brain (Conner et al., 1997; Yan et al., 1997). However, it has not been shown previously that BDNF is expressed in sprouted mossy fibers of pilocarpine-treated rats. There is one report of BDNF in mossy fiber sprouting in a different rat model of epilepsy, in which a period of stimulation of the hippocampus leads to spontaneous seizures (Bertram, 1997); BDNF was expressed in some of the sprouted fibers (Vezzani et al., 1999).

To determine whether BDNF was expressed in the sprouted
Figure 8. Effects of BDNF in slices with sprouting were not altered by NMDA receptor antagonism. $A$, Spontaneous epileptiform activity was recorded in the inner molecular layer in a slice that had mossy fiber sprouting and was exposed to BDNF (200 ng/ $\mathrm{ml}$ ) for $70 \mathrm{~min}$. Note that there was some variability in the number of repetitive events comprising the epileptiform activity. In $A 1$, there are 13 in the example on the left and 12 in the example on the right. They were recorded 9 and $10 \mathrm{~min}$, respectively, before slices were exposed to $50 \mu \mathrm{M}$ D-APV. The epileptiform activity shown in $A 2$ was recorded $30 \mathrm{~min}$ after APV was added to the buffer containing BDNF. Calibration (shown in $B$ ): $5 \mathrm{mV}, 1$ sec. $B$, The spontaneous activity shown in $A 1$, on the left, is illustrated with a different time base. Calibration: $5 \mathrm{mV}, 400$ msec.

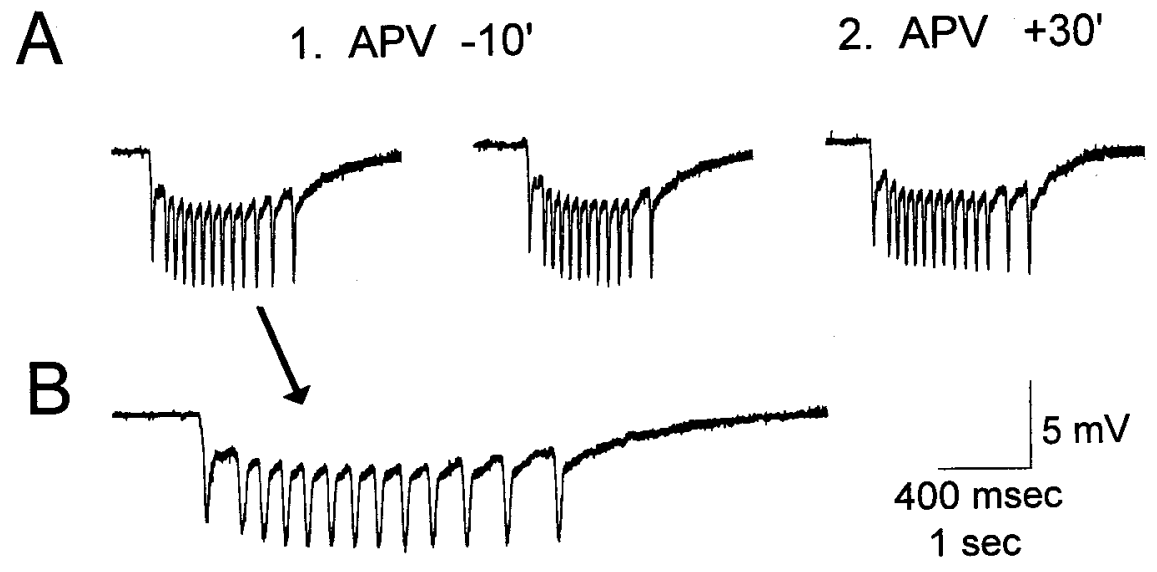



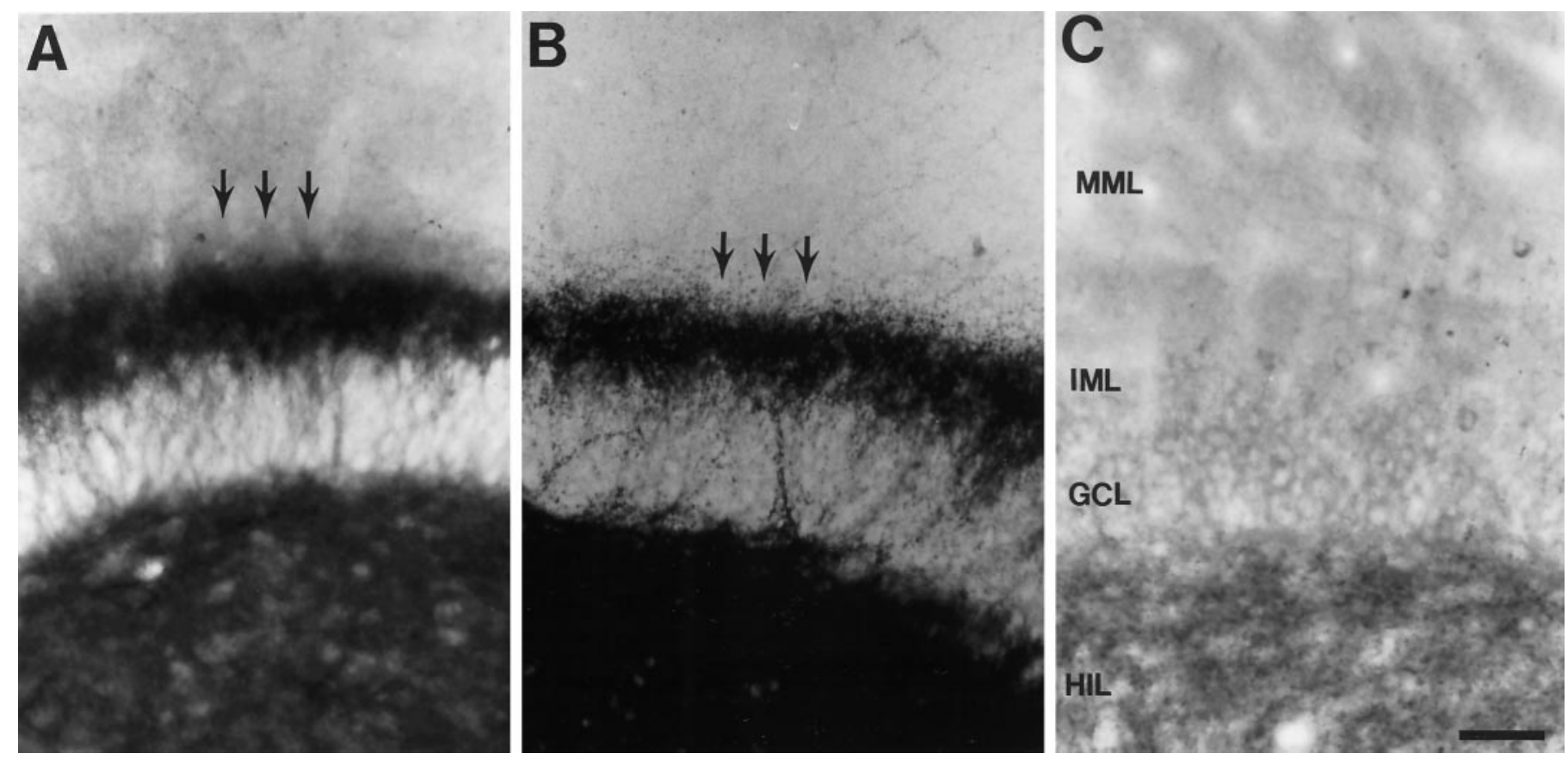

Figure 9. Timm stain and BDNF immunocytochemistry in sprouted and unsprouted tissue. A, A section from the dentate gyrus of a rat with mossy fiber sprouting, stained with an antibody to BDNF, shows that BDNF was expressed in hilus and the inner molecular layer sprouted plexus (arrows). The lamina of the dentate gyrus $(C)$ are indicated by abbreviations of the layers and apply to $A-C$. $H I L$, Hilus; $G C L$, granule cell layer; $I M L$, inner molecular layer; $M M L$, middle molecular layer. Scale bar (shown in $C$ for $A-C$ ): $100 \mu \mathrm{m}$. B. Timm stain of a section from the same rat as used for $A$ illustrates the mossy fiber plexus in the hilus and inner molecular layer (arrows). $C$, BDNF staining in a rat that was administered pilocarpine but did not have status epilepticus thereafter, and subsequently did not have behavioral seizures, did not express BDNF in the inner molecular layer.

fibers of our pilocarpine-treated rats, four animals that received pilocarpine, had status epilepticus, and had spontaneous seizures were perfusion-fixed and stained with an antibody to BDNF (Fig. 9). Alternate sections were stained by the Timm method in two cases to compare the location of mossy fiber sprouted axons, defined by Timm stain, with BDNF immunoreactivity. As shown in Figure $9 A, B$, when there was Timm staining of the hilus and inner molecular layer there also was BDNF immunoreactivity in those areas. However, Timm stain and BDNF immunoreactivity were weak in the outer twothirds of the molecular layer and the granule cell layer. Three pilocarpine-treated rats that did not have status epilepticus and did not exhibit sprouting did not display Timm or BDNF immunoreactivity in the inner molecular layer (Fig. 9C). In the animals without sprouting, the hilus was the major site of immunoreactivity, similar to the normal adult rat. Because preferential staining of the hilus and inner molecular layer with Timm stain is often taken to be a reflection of the mossy fibers, the results indicate by analogy that sprouted mossy fibers in the pilocarpine animal model of epilepsy contain BDNF protein. However, whether there is perfect correspondence between mossy fibers containing zinc and BDNF is presently unclear. We hypothesize that endogenous BDNF in sprouted mossy fibers could enhance excitability in the dentate gyrus similar to the actions of exogenous BDNF that have been described here (see Discussion).

\section{DISCUSSION}

\section{Summary}

Specificity of BDNF's actions at mossy fibers

The results demonstrate that BDNF enhances excitatory transmission of mossy fibers to granule cells of pilocarpine-treated rats with mossy fiber sprouting. This is similar to the effects of BDNF on excitatory transmission of mossy fibers to CA3 pyramidal cells in normal rats (Scharfman, 1997). Thus, in both normal and pilocarpine-treated rats, prolonged (30-60 $\mathrm{min}$ ) exposure to BDNF was necessary before effects were detected, evoked responses and paired-pulse inhibition of granule cells to molecular layer stimulation were relatively unaffected, and K252a blocked the effects of BDNF. These results suggest that in both normal rats and pilocarpine-treated rats, BDNF activates trkB receptors, which in turn alter mossy fiber transmission. This is also supported by the lack of effect of NMDA receptor antagonists. Thus, the effects of bath-applied BDNF appear to be specific for mossy fiber transmission, even after substantial changes in structure and function that occur in pilocarpine-treated rats with sprouting.

This specificity could arise by a number of mechanisms. Perhaps the most parsimonious is that trkB receptors are located preferentially at mossy fiber boutons. However, it is also possible that a particular target protein of trkB is present in mossy fibers preferentially, although trkB itself is localized nonspecifically. It is important to note as a caveat that every example of mossy fiber transmission was not examined in this study, such as mossy fiber transmission to inhibitory neurons. Therefore, it is possible that there are exceptions to the finding that BDNF enhances mossy fiber transmission.

\section{BDNF-induced hyperexcitability in pilocarpine-treated rats with sprouting}

A second conclusion of this study was that BDNF induced hyperexcitability of granule cells in slices from pilocarpine-treated rats with mossy fiber sprouting. Thus, spontaneous granule cell discharges occurred after BDNF exposure, and this only occurred if there was sprouting. This is remarkable because granule cells are hyperpolarized neurons (Spruston and Johnston, 1992; 
Staley et al., 1992; Williamson et al., 1993), with a resting potential far from threshold. Granule cells are also strongly inhibited by tonic release of GABA (Otis et al., 1991). Spontaneous discharges of granule cells, or large spontaneous EPSCs of granule cells, have been reported previously in a subset of granule cells from sprouted rats after administration of a $\mathrm{GABA}_{\mathrm{A}}$ receptor antagonist (bicuculline) in a buffer containing lower $\left[\mathrm{Mg}^{2+}\right]_{\mathrm{o}}$ than used in our experiments (1.3 mm vs $2 \mathrm{~mm}$ ) (Cronin et al., 1992; Simmons et al., 1997). Thus, BDNF has a strong effect in the sprouted dentate gyrus.

Spontaneous discharges became prolonged, seizure-like events after exposure to both BDNF and bicuculline. In previous studies of kainic acid-induced mossy fiber sprouting, such seizure-like events have been reported after administration of bicuculline and increased extracellular potassium $\left(6 \mathrm{mM} \mathrm{K}^{+}\right.$) (Wuarin and Dudek, 1996). Thus, it appears that prolonged, seizure-like events in sprouted tissue occur after disinhibition and either BDNF or increased $\left[\mathrm{K}^{+}\right]_{\mathrm{o}}$. The fact that both BDNF and increased $\left[\mathrm{K}^{+}\right]_{\mathrm{o}}$ promote increased transmitter release suggests that disinhibition, coupled to increased glutamate release from mossy fibers, may be critical regulators of seizure-like discharge in sprouted rats.

\section{Implications for understanding functional consequences of cortical reorganization}

Although often thought of in the context of epilepsy, one perspective on mossy fiber sprouting is that it is an example of reorganization after brain injury. Thus, it has been proposed that pilocarpine-induced seizures that kill the target neurons of mossy fibers induce sprouting (Cavazos and Sutula, 1990; Buckmaster and Dudek, 1997; but see Stringer et al., 1997). Our results suggest that BDNF actions on synaptic transmission may be preserved after brain injury and consequent alterations in circuitry. From this, one would predict that neurons that become innervated by terminals that are normally modulated by BDNF may develop sensitivity to BDNF. This could have important implications for the events that become possible in reorganized cortical circuits, ranging from potentiation to hyperexcitability.

\section{Implications for understanding actions of endogenous BDNF}

Immunocytochemistry showed that BDNF protein is present in the reorganized axons of mossy fibers, which has recently been reported in another animal model of epilepsy (Vezzani et al., 1999). Thus, the effects of exogenous BDNF that have been described may foretell the actions of endogenous BDNF that exists in sprouted mossy fibers. If endogenous BDNF reaches concentrations similar to the concentrations of bath-applied BDNF that were used in the above experiments, the actions of endogenous and bath-applied BDNF could be similar. Even if normal concentrations of BDNF are low, endogenous BDNF still might have functional effects under certain conditions, because BDNF message, protein, and trkB expression increase after various events (such as after neuronal activity, sensory stimulation, learning, long-term potentiation, stress, injury, and seizures) (Ballarín et al., 1991; Zafra et al., 1991; Falkenberg et al., 1992a,b; Lindefors et al., 1992; Lindvall et al., 1992, 1994; Patterson et al., 1992; Beck et al., 1993; Castrén et al., 1993; Cosi et al., 1993; Dragunow et al., 1993; Humpel et al., 1993; Lapchak et al., 1993; Merlio et al., 1993; Springer et al., 1994; Lauterborn et al., 1995; Nibuya et al., 1995; Arai et al., 1996; Bramham et al., 1996; Mudò et al., 1996; Schmidt-Kastner et al., 1996; Kawahara et al., 1997; Vaidya et al., 1997; Bova et al., 1998; Oliff et al., 1998).
It is hypothesized that endogenous BDNF would bind to trkB receptors on mossy fiber terminals, and the end result would be phosphorylation of a protein involved in presynaptic regulation of glutamate release. A candidate protein is synapsin I, which has been shown to be phosphorylated by BDNF (Jovanic et al., 1996). There are also other possible sites of actions, such as truncated trkB receptors on glia, particularly in light of the demonstration that truncated trkB receptors are increased in non-neuronal cells after lesions to dentate gyrus afferents (Beck et al., 1993). The data reported here suggest that at least one action would be at mossy fiber terminals. The prediction is that excitability of granule cells would increase as a result of endogenous BDNF action.

The results of experiments with bicuculline, which showed that disinhibition can prolong BDNF-induced spontaneous discharges into epileptiform, seizure-like events, suggest that the actions of endogenous BDNF would be enhanced when dentate granule cells became disinhibited. Disinhibition in normal behaving animals could occur in several ways, such as during a change in septal input, because septal afferents preferentially target dentate GABAergic neurons; the raphe is another input that targets dentate interneurons preferentially (Freund, 1992). Another type of naturally occurring event that appears to disinhibit the dentate gyrus is a sharp wave (Buzsáki, 1986). Thus, if BDNF release occurred in conjunction with a disinhibitory event, one would predict that endogenous BDNF could provoke seizure-like activity among granule cells in a sprouted dentate gyrus.

The hypothesis that endogenous BDNF may contribute to hyperexcitability is consistent with previous investigations of BDNF in vivo. Kokaia et al. (1995) reported that kindling was suppressed in heterozygotes lacking the BDNF gene (homozygotes did not survive). Binder and colleagues (1996) demonstrated that animals receiving intraventricular infusion of trkBIgG, which binds to BDNF and prevents its interaction with trkB receptors, required more stimulations to be kindled. However, other studies suggest the opposite. Larmet et al. (1995) and Reibel et al. (1996) showed that animals that had received chronic BDNF infusions had fewer tonic-clonic seizures after injection of the convulsant pentylenetetrazol. Osehobo et al. (1999) found that animals receiving chronic dentate hilar infusions of BDNF required more stimulations for kindling. One possible reason for the discrepancy is that chronic BDNF infusion may alter BDNF message, protein, or trkB receptor expression and function. Indeed, long exposure of cultures to BDNF downregulates trkB levels and responsiveness (Frank et al., 1996).

\section{Implications for understanding spontaneous seizures in sprouted rats and temporal lobe epileptics}

The consequences of BDNF-induced spontaneous discharges of granule cells are important to consider. Could such events precipitate limbic seizures of pilocarpine-treated rats with sprouting? Furthermore, could BDNF contribute to seizures in temporal lobe epilepsy, given that human mossy fibers express BDNF (Murer et al., 1999), temporal lobe epileptics demonstrate mossy fiber sprouting (Sutula et al., 1989), and human granule cells express increased BDNF mRNA after seizures (Mathern et al., 1997)? Certainly these are tempting conclusions, but they would be premature.

Hypothetically, discharges in granule cells could lead to limbic seizures. However, the extent to which such activity contributes to seizures is difficult to predict, because it would depend on several factors, such as the number of hippocampal pyramidal neurons that survive after pilocarpine treatment, which would be 
critical to propagation of activity out of the hippocampus. Seizure-induced changes in structure and function should not be underestimated, given their diversity and robust nature (Gall et al., 1990; Sheng and Greenberg, 1990; Cavalheiro et al., 1992; Sperk et al., 1992, 1996; Gall, 1993; Lynch et al., 1996; Vezzani et al., 1996; Parent et al., 1997). Certainly some seizure-induced changes in gene expression, such as the increase in BDNF and trkB after seizures, would make it more likely that BDNF would induce abnormal granule cell discharges after seizures. Nevertheless, the entire spectrum of changes that occur after seizures, and the effects of endogenous BDNF, need to be clarified before it can be concluded that endogenous BDNF contributes to seizures in pilocarpine-treated rats or humans with temporal lobe epilepsy.

\section{REFERENCES}

Acheson A, Conover JC, Fandl JP, DeChiara TM, Russell M, Thadani A, Squinto SP, Yancopoulos GD, Lindsay RM (1995) A BDNF autocrine loop in adult sensory neurons prevents cell death. Nature 374:450-452.

Alderson RF, Alterman AL, Barde Y-A, Lindsay RM (1990) Brainderived neurotrophic factor increases survival and differentiated functions of rat septal cholinergic neurons in culture. Neuron 5:297-306.

Arai S, Kinouchi H, Akabane A, Owada Y, Kamii H, Kawase M, Yoshimoto T (1996) Induction of brain-derived neurotrophic factor (BDNF) and the receptor trkB mRNA following middle cerebral artery occlusion in rat. Neurosci Lett 211:57-60.

Ballarín M, Ernfors P, Lindefors N, Persson H (1991) Hippocampal damage and kainic acid injection induce a rapid increase in mRNA for BDNF and NGF in the rat brain. Exp Neurol 114:35-43.

Beck KD, Lamballe F, Klein R, Barbacid M, Schauwecker PE, McNeill TH, Finch CE, Hefti F, Day JR (1993) Induction of noncatalytic trkB neurotrophin receptors during axonal sprouting in the adult hippocampus. J Neurosci 13:4001-4014.

Beck T, Lindholm D, Castrén E, Wree A (1994) Brain-derived neurotrophic factor protects against ischemic cell damage in rat hippocampus. J Cereb Blood Flow Metab 14:689-692.

Bertram EH (1997) Functional anatomy of spontaneous seizures in a rat model of limbic epilepsy. Epilepsia 38:95-105.

Bova R, Micheli MR, Qualadrucci P, Zucconi GG (1998) BDNF and trkB mRNAs oscillate in rat brain during the light-dark cycle. Mol Brain Res 57:321-324.

Bramham CR, Southard T, Sarvey JM, Herkenham M, Brady LS (1996) Unilateral LTP triggers bilateral increases in hippocampal neurotrophin and trk receptor mRNA expression in behaving rats: evidence for interhemispheric communication. J Comp Neurol 368:371-382.

Buckmaster PS, Dudek FE (1997) Neuron loss, granule cell axon reorganization and functional changes in the dentate gyrus of epileptic kainate-treated rats. J Comp Neurol 385:385-404.

Buzsáki G (1986) Hippocampal sharp waves: their origin and significance. Brain Res 398:232-252.

Carmignoto G, Pizzorusso T, Tia S, Vicini S (1997) Brain-derived neurotrophic factor and nerve growth factor potentiate excitatory synaptic transmission in the rat visual cortex. J Physiol (Lond) 498:153-164.

Castrén E, Pitkänen M, Sirviö J, Parsadanian A, Lindhom D, Thoenen H, Riekkinen PJ (1993) The induction of LTP increases BDNF and NGF mRNA but decreases NT-3 mRNA in the dentate gyrus. NeuroReport 4:895-898.

Cavalheiro EA, Fernandes MJ, Turski L, Mazzacoratti MG (1992) Neurochemical changes in the hippocampus of rats with spontaneous recurrent seizures. Epilepsy Res [Suppl] 9:239-247.

Cavazos JE, Sutula TP (1990) Progressive neuronal loss induced by kindling: a possible mechanism of mossy fiber synaptic reorganization and hippocampal sclerosis. Brain Res 527:1-6.

Chafetz RS, Namh WK, Noebels JL (1995) Aberrant expression of neuropeptide $\mathrm{Y}$ in hippocampal mossy fibers in the absence of local cell injury following the onset of spike wave synchronisation. Mol Brain Res 31:111-121.

Cheng B, Mattson MP (1994) NT-3 and BDNF protect CNS neurons against metabolic/excitotoxic insults. Brain Res 640:56-67.

Conner JM, Lauterborn JC, Yan Q, Gall CM, Varon S (1997) Distribution of brain-derived neurotrophic factor (BDNF) protein and mRNA in the normal adult rat CNS: evidence for anterograde axonal transport. J Neurosci 17:2295-2313.
Cosi C, Spoerri PE, Comelli MC, Guidolin D, Skaper SD (1993) Glucocorticoids depress activity-dependent expression of BDNF mRNA in hippocampal neurons. NeuroReport 4:527-532.

Cronin J, Obenaus A, Houser CR, Dudek FE (1992) Electrophysiology of dentate granule cells after kainate-induced synaptic reorganization. Brain Res 573:305-310.

Deller T, Leranth C (1990) Synaptic connections of neuropeptide Y (NPY): immunoreactive neurons in the hilar area of the rat hippocampus. J Comp Neurol 300:433-447.

Dragunow M, Beilharz E, Mason B, Lawlor P, Abraham W, Gluckman P (1993) Brain-derived neurotrophic factor expression after long-term potentiation. Neurosci Lett 160:232-236.

Du F, Eid T, Lothman EW, Köhler C, Schwarcz R (1995) Preferential neuronal loss in layer III of the medial entorhinal cortex in rat models of temporal lobe epilepsy. J Neurosci 15:6301-6313.

Ernfors P, Bengzon J, Kokaia Z, Persson H, Lindvall O (1991) Increased levels of mRNAs for neurotrophic factors in the brain during kindling epileptogenesis. Neuron 7:165-176.

Falkenberg T, Ernfors P, Persson H, Lindefors N (1992a) Cortical transsynaptic activation of tyrosine kinase receptor trkB messenger RNA expression in rat hippocampus. Neuroscience 51:883-889.

Falkenberg T, Mohammed AK, Henriksson B (1992b) Increased expression of brain derived neurotrophic factor mRNA in rat hippocampus is associated with improved spatial memory and enriched environment. Neurosci Lett 138:153-156.

Figurov A, Pozzo-Miller LD, Olafsson P, Wang T, Lu B (1996) Regulation of synaptic responses to high-frequency stimulation and LTP by neurotrophins in the hippocampus. Nature 381:706-709.

Frank L, Ventimiglia R, Anderson K, Lindsay RM, Rudge JS (1996) BDNF down-regulates neurotrophin responsiveness, trkB protein and trkB mRNA levels in cultured rat hippocampal neurons. Eur J Neurosci $8: 1220-1230$

Freund TF (1992) GABAergic septal and serotonergic median raphe afferents preferentially innervate inhibitory interneurons in the hippocampus and dentate gyrus. In: The dentate gyrus and its role in seizures (Ribak CE, Gall CM, Mody I, eds), pp 79-91. Amsterdam: Elsevier.

Gall C, Lauterborn J, Isackson P, White J (1990) Seizures, neuropeptide regulation and mRNA expression in the hippocampus. Prog Brain Res $83: 371-390$

Gall CM (1993) Seizure-induced changes in neurotrophin expression: implications for epilepsy. Exp Neurol 124:150-166.

Ghosh A, Carnahan J, Greenberg ME (1994) Requirement for BDNF in activity-dependent survival of cortical neurons. Science 263:1618-1623.

Gottschalk W, Pozzo-Miller LD, Figurov A, Lu B (1998) Presynaptic modulation of synaptic transmission and plasticity by brain-derived neurotrophic factor in the developing hippocampus. J Neurosci 18:6830-6836

Gruber B, Greber S, Rupp E, Sperk G (1994) Differential NPY mRNA expression in granule cells and interneurons of the rat dentate gyrus after kainic acid injection. Hippocampus 4:474-482.

Hofer MM, Barde Y-A (1988) Brain-derived neurotrophic factor prevents neuronal death in vivo. Nature 331:261-262.

Humpel C, Wetmore C, Olson L (1993) Regulation of brain-derived neurotrophic factor messenger RNA and protein at the cellular level in pentylenetetrazol-induced epileptic seizures. Neuroscience 53:909-918.

Isackson PJ, Huntsman MM, Murray KD, Gall CM (1991) BDNF mRNA expression is increased in adult rat forebrain after limbic seizures: temporal patterns of induction distinct from NGF. Neuron 6:937-948.

Jarvis CR, Xiong Z-G, Plant JR, Churchill D, Lu W-Y, MacVicar BA, MacDonald JF (1997) Neurotrophin modulation of NMDA receptors in cultured murine and isolated rat neurons. $\mathrm{J}$ Neurophysiol 78:2363-2371.

Jovanic JN, Benfenati F, Siow YL, Sihra TS, Sanghera JS, Pelech SL, Greengard P, Czernik AJ (1996) Neurotrophins stimulate phosphorylation of synapsin I by MAP kinase and regulate synapsin I actin interactions. Proc Natl Acad Sci USA 93:3679-3683.

Kang H, Schuman EM (1995) Long-lasting neurotrophin-induced enhancement of synaptic transmission in the adult hippocampus. Science 267:1658-1662.

Kawahara N, Croll SD, Wiegand SJ, Klatzo I (1997) Cortical spreading depression induces long-term alterations of BDNF levels in cortex and 
hippocampus distinct from lesion effects: implications for ischemic tolerance. Neurosci Res 29:37-47.

Kim HG, Wang T, Olafsson P, Lu B (1994) Neurotrophin 3 potentiates neuronal activity and inhibits gamma-amino butyratergic synaptic transmission in cortical neurons. Proc Natl Acad Sci USA 91:12341-12345.

Knüsel B, Winslow JW, Rosenthal A, Burton LE, Seid DP, Nikolics K, Hefti F (1991) Promotion of central cholinergic and dopaminergic neuron differentiation by brain-derived neurotrophic factor but not neurotrophin-3. Proc Natl Acad Sci USA 88:961-965.

Köhler C, Eriksson L, Davies S, Chan-Palay V (1986) Neuropeptide Y innervation of the hippocampal region in the rat and monkey brain. J Comp Neurol 244:384-400.

Kokaia Z, Othberg A, Kokaia M, Lindvall O (1994) BDNF makes cultured dentate granule cells more resistant to hypoglycemic damage. NeuroReport 5:1241-1244.

Kokaia M, Ernfors P, Kokaia Z, Elmer E, Jaenisch R, Lindvall O (1995) Suppressed epileptogenesis in BDNF mutant mice. Exp Neurol 133:215-224.

Kotti T, Riekkinen PJ, Miettinen R (1997) Characterization of target cells for aberrant mossy fiber collaterals in the dentate gyrus of epileptic rat. Exp Neurol 146:323-330.

Lapchak PA, Araujo DM, Hefti F (1993) Systemic interleukin-1 $\beta$ decreases brain-derived neurotrophic factor messenger RNA expression in the rat hippocampal formation. Neuroscience 53:297-301.

Larmet Y, Reibel S, Carnahan J, Nawa H, Marescaux C, Depaulis A (1995) Protective effects of brain derived neurotrophic factor on the development of hippocampal kindling in the rat. NeuroReport 6:1937-1941.

Lauterborn J, Berschauer R, and Gall CM (1995) Cell-specific modulation of basal and seizure induced neurotrophin expression by adrenalectomy. Neuroscience 68:363-378.

Le $\beta$ man V, Heumann R (1998) Modulation of unitary glutamatergic synapses by neurotrophin $4 / 5$ or brain derived neurotrophic factor in hippocampal microcultures: presynaptic enhancement depends on preestablished paired-pulse facilitation. Neuroscience 86:399-413.

Le $\beta$ mann V, Gottmann K, Heumann R (1994) BDNF and NT-4/5 enhance glutamatergic synaptic transmission in cultured hippocampal neurones. NeuroReport 6:21-25.

Levine ES, Dreyfus CF, Black IB, Plummer MR (1995) Brain-derived neurotrophic factor rapidly enhances synaptic transmission in hippocampal neurons via postsynaptic tyrosine kinase receptors. Proc Natl Acad Sci USA 92:8074-8077.

Levine ES, Dreyfus CF, Black IB, Plummer MR (1996) Selective role for trkB neurotrophin receptors in rapid modulation of hippocampal synaptic transmission. Mol Brain Res 38:300-303.

Levine ES, Crozier RA, Black IB, Plummer MR (1998) Brain-derived neurotrophic factor modulates hippocampal synaptic transmission by increasing $N$-methyl-D-aspartate receptor activity. Proc Natl Acad Sci USA 95:10235-10239.

Li Y-X, Zhang Y, Lester HA, Schuman EM, Davidson N (1998) Enhancement of neurotransmitter release induced by brain-derived neurotrophic factor in cultured hippocampal neurons. J Neurosci 18:10231-10240.

Lin SY, Wu K, Levine ES, Mount HTJ, Suen PC, Black IB (1998) BDNF rapidly enhances tyrosine phosphorylation of NMDA receptor subunit $2 \mathrm{~B}$ in postsynaptic densities of rat cerebral cortex and hippocampus. Mol Brain Res 55:20-27.

Lindefors N, Ernfors P, Falkenberg T, Persson H (1992) Septal cholinergic afferents regulate expression of brain-derived neurotrophic factor and $\beta$-nerve growth factor mRNA in rat hippocampus. Exp Brain Res 88:78-90.

Lindholm D, Dechant G, Heisenberg C-P, Thoenen H (1993) Brainderived neurotrophic factor is a survival factor for cultured rat cerebellar granule neurons and protects them against glutamate-induced neurotoxicity. Eur J Neurosci 5:1455-1464.

Lindvall O, Ernfors P, Bengzon J, Kokaia Z, Smith M-L, Siesjö BK, Persson H (1992) Differential regulation of mRNAs for nerve growth factor, brain-derived neurotrophic factor, and neurotrophin-3 in the adult rat brain following cerebral ischemia and hypoglycemic coma. Proc Natl Acad Sci USA 89:648-652.

Lindvall O, Kokaia Z, Bengzon J, Elmer E, Kokaia M (1994) Neurotrophins and brain insults. Trends Neurosci 17:490-496.

Lohof AM, Ip NY, Poo M-M (1993) Potentiation of developing neuro- muscular synapses by the neurotrophins NT-3 and BDNF. Nature 363:350-353.

Lowenstein DH, Arsenault L (1996) The effects of growth factors on the survival and differentiation of cultured dentate gyrus neurons. J Neurosci 16:1759-1769.

Lurton D, Cavalheiro EA (1997) Neuropeptide Y immunoreactivity in the pilocarpine model of temporal lobe epilepsy. Exp Brain Res 116:186-190.

Lynch MW, Rutecki PA, Sutula TP (1996) The effects of seizures on the brain. Curr Opin Neurol 9:97-102.

Mathern GW, Babb TL, Micevych PE, Blanco CE, Pretorius JK (1997) Granule cell mRNA levels for BDNF, NGF, and NT-3 correlate with neuron losses or supragranular mossy fiber sprouting in the chronically damaged and epileptic human hippocampus. Mol Chem Neuropathol 30:53-76.

McAllister AK, Lo DC, Katz LC (1995) Neurotrophins regulate dendritic growth in developing visual cortex. Neuron 15:791-803.

Mello LEAM, Cavalheiro EA, Babb TL, Kupfer WR, Pretorius JK, Tan AM, Finch DM (1993) Circuit mechanisms of seizures in the pilocarpine model of chronic epilepsy: cell loss and mossy fiber sprouting. Epilepsia 34:985-995.

Merlio J-P, Ernfors P, Kookaia Z, Middlemas DS, Bengzon J, Kokaia M, Smith M-L, Siesjö BK, Hunter T, Lindvall O, Persson H (1993) Increased production of the trkB protein tyrosine kinase receptor after brain insults. Neuron 10:151-164.

Messaoudi E, Bårdsen K, Srebro B, Bramham CR (1998) Acute intrahippocampal infusion of brain-derived neurotrophic factor induces lasting potentiation of synaptic transmission in the rat dentate gyrus. J Neurophysiol 79:496-499.

Milner TA, Veznedaroglu E (1992) Ultrastructural localization of neuropeptide-Y-like immunoreactivity in the rat hippocampal formation. Hippocampus 2:107-116.

Morse JK, Wiegand SJ, Anderson K, You Y, Cai N, Carnahan J, Miller J, DiStefano PS, Altar CA, Lindsay RM, Alderson RF (1993) Brainderived neurotrophic factor (BDNF) prevents the degeneration of medial septal cholinergic neurons following fimbria transection. J Neurosci 13:4146-4156.

Mudò G, Jiang XH, Timmuske T, Bindoni M, Belluardo N (1996) Change in neurotrophins and their receptor mRNAs in the rat forebrain after status epilepticus induced by pilocarpine. Epilepsia 37:198-207.

Murer MG, Boissiere F, Yan Q, Huno S, Villares J, Faucheux B, Agid Y, Hirsch E, Raisman-Vozari R (1999) An immunohistochemical study of the distribution of brain-derived neurotrophic factor in the adult human brain, with particular reference to Alzheimer's disease. Neuroscience 88:1015-1032.

Nibuya M, Morinobu S, Duman RS (1995) Regulation of BDNF and trkB mRNA in rat brain by chronic electroconvulsive seizure and antidepressant drug treatments. J Neurosci 15:7539-7547.

Okazaki MM, Evenson DA, Nadler JV (1995) Hippocampal mossy fiber sprouting and synapse formation after status epilepticus in rats: visualization after retrograde transport of biocytin. J Comp Neurol 352:515-534

Oliff HS, Berchtold NC, Isackson P, Cotman CW (1998) Exercise induced regulation of brain derived neurotrophic factor (BDNF) transcripts in the rat hippocampus. Mol Brain Res 61:147-153.

Osehobo P, Adams B, Sazgar M, Xu Y, Racine R, Fahnestock M (1999) Brain-derived neurotrophic factor infusion delays amygdala and perforant path kindling without affecting paired pulse measures of neuronal inhibition in adult rats. Neuroscience, in press.

Otis TS, Staley KJ, Mody I (1991) Perpetual inhibitory activity in mammalian brain slices generated by spontaneous GABA release. Brain Res 545:142-150.

Parent JM, Yu TW, Leibowitz RT, Geschwind DH, Sloviter RS, Lowenstein DH (1997) Dentate granule cell neurogenesis is increased by seizures and contributes to aberrant network reorganization in the adult rat hippocampus. J Neurosci 17:3727-3738.

Patterson SL, Abel T, Deuel TAS, Martin KC, Rose JC, Kandel ER (1996) Recombinant BDNF rescues deficits in basal synaptic transmission and hippocampal LTP in BDNF knockout mice. Neuron 16:1137-1145.

Patterson SL, Grover LM, Schwartzkroin PA, Bothwell M (1992) Neurotrophin expression in rat hippocampal slices: a stimulus paradigm inducing LTP in CA1 evokes increases in BDNF and NT-3 mRNAs. Neuron 9:1081-1088. 
Racine RJ (1972) Modification of seizure activity by electrical stimulation. II. Motor seizure. Electroencephalogr Clin Neurophysiol 32:281-294.

Rudge JS, Mather PE, Pasnikowski EM, Ning C, Corcoran T, Acheson A, Anderson K, Lindsay RM, Wiegand SJ (1998) Endogenous BDNF protein is increased in adult rat hippocampus after a kainic acid induced excitotoxic insult but exogenous BDNF is not neuroprotective. Exp Neurol 149:398-410.

Scharfman HE (1995) Electrophysiological diversity of pyramidalshaped neurons at the granule cell layer/hilus border of the rat dentate gyrus recorded in vitro. Hippocampus 5:89-127.

Scharfman HE (1997) Hyperexcitability in combined entorhinal/hippocampal slices of adult rat after exposure to brain-derived neurotrophic factor. J Neurophysiol 78:1082-1095.

Schmidt-Kastner R, Humpel C, Wetmore C, Olson L (1996) Cellular hybridization for BDNF, trkB, and NGF mRNAs and BDNFimmunoreactivity in rat forebrain after pilocarpine-induced status epilepticus. Exp Brain Res 107:331-347.

Sheng M, Greenberg ME (1990) The regulation and function of c-fos and other immediate early genes in the nervous system. Neuron $4: 477-485$.

Simmons ML, Terman GW, Chavkin C (1997) Spontaneous excitatory currents and kappa-opioid receptor inhibition in dentate gyrus are increased in the rat pilocarpine model of temporal lobe epilepsy. J Neurophysiol 78:1860-1868.

Sloviter RS (1982) A simplified Timm stain procedure compatible with formaldehyde fixation and routine paraffin embedding of rat brain. Brain Res Bull 8:771-774.

Sloviter RS (1991) Permanently altered hippocampal structure, excitability, and inhibition after experimental status epilepticus in the rat: the "dormant basket cell" hypothesis and its possible relevance to temporal lobe epilepsy. Hippocampus 1:41-66.

Sloviter RS (1992) Possible functional consequences of synaptic reorganization in the dentate gyrus of kainate-treated rats. Neurosci Lett 137:91-96.

Sperk G, Marksteiner J, Gruber B, Bellmann R, Mahata M, Ortler M (1992) Functional changes in neuropeptide $\mathrm{Y}$ and somatostatin containing neurons induced by limbic seizures in the rat. Neuroscience 50:831-846.

Sperk G, Bellmann R, Gruber B, Greber S, Marksteiner J, Roder C, Rupp E (1996) Neuropeptide Y expression in animal models of temporal lobe epilepsy. Epilepsy Res [Suppl] 12:197-203.

Spina MB, Squinto SP, Miller J, Lindsay RM, Hyman C (1992) Brainderived neurotrophic factor protects dopamine neurons against 6-hydroxydopamine and $N$-methyl-D-phenylpyridinium ion toxicity: involvement of the glutathione system. J Neurochem 59:99-106.

Springer JE, Gwag BJ, Sessler FM (1994) Neurotrophic factor mRNA expression in dentate gyrus is increased following in vivo stimulation of the angular bundle. Mol Brain Res 23:135-143.

Spruston N, Johnston D (1992) Perforated patch clamp analysis of passive membrane properties of three classes of hippocampal neurons. J Neurophysiol 67:508-529.

Staley KJ, Otis TS, Mody I (1992) Membrane properties of dentate gyrus granule cells: comparison of sharp microelectrode and whole-cell recordings. J Neurophysiol 67:1346-1358.

Stringer JL, Agarwal KS, Dure LS (1997) Is cell death necessary for hippocampal mossy fiber sprouting? Epilepsy Res 27:67-76.

Suen PC, Wu K, Levine ES, Mount HTJ, Xu JL, Lin SY, Black IB (1997) Brain-derived neurotrophic factor rapidly enhances phosphorylation of the postsynaptic $N$-methyl-D-aspartate receptor subunit 1 . Proc Natl Acad Sci USA 94:8191-8195.

Sutula T, Cascino G, Cavazos J (1989) Mossy fiber synaptic reorganization in the epileptic human temporal lobe. Ann Neurol 26:321-330.

Takei N, Sasaoka K, Inoue K, Takahashi M, Endo Y, Hatanaka H (1997) Brain-derived neurotrophic factor increases the stimulation-evoked release of glutamate and the levels of exocytosis-associated proteins in cultured cortical neurons from embryonic rats. J Neurochem 68:370-375.

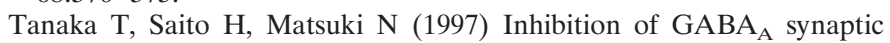
responses by brain derived neurotrophic factor (BDNF) in rat hippocampus. J Neurosci 17:2959-2966.

Tauck DL, Nadler JV (1985) Evidence of functional mossy fiber sprouting in hippocampal formation of kainic acid treated rats. J Neurosci 5:1016-1022.

Vaidya VA, Marek GJ, Aghajanian GK, Duman RS (1997) 5- $\mathrm{HT}_{2 \mathrm{~A}}$ receptor-mediated regulation of brain-derived neurotrophic factor mRNA in the hippocampus and the neocortex. J Neurosci 17:2785-2795.

Vezzani A, Schwarzer C, Lothman EW, Williamson J, Sperk G (1996) Functional changes in somatostatin and neuropeptide Y containing neurons in the rat hippocampus in chronic models of limbic seizures. Epilepsy Res 26:267-279.

Vezzani A, Ravizza T, Moneta D, Conti M, Borroni A, Rizzi M, Samanin R, Maj R (1999) Brain-derived neurotrophic factor immunoreactivity in the limbic system of rats after acute seizures and during spontaneous convulsions: temporal evolution of changes as compared to neuropeptide Y. Neuroscience, in press.

Williamson A, Spencer DD, Shepherd GM (1993) Comparison between the membrane and synaptic properties of human and rodent dentate granule cells. Brain Res 622:194-202.

Wuarin JP, Dudek FE (1996) Electrographic seizures and new recurrent excitatory circuits in the dentate gyrus of hippocampal slices from kainate-treated epileptic rats. J Neurosci 16:4438-4448.

Yan Q, Elliott J, Snider WJ (1992) Brain-derived neurotrophic factor rescues spinal motor neurons from axotomy-induced cell death. Nature 360:753-755.

Yan Q, Rosenfeld RD, Matheson CR, Hawkins N, Lopez OT, Bennett L, Welcher AA (1997) Expression of brain-derived neurotrophic factor protein in the adult rat central nervous system. Neuroscience 78:431-448.

Zafra F, Castrén E, Thoenen H, Lindholm D (1991) Interplay between glutamate and gamma-aminobutyric acid transmitter systems in the physiological regulation of brain-derived neurotrophic factor and nerve growth factor synthesis in hippocampal neurons. Proc Natl Acad Sci USA 88:10037-10041. 